\title{
Effect of dietary protein level and rumen-protected amino acid supplementation on amino acid utilization for milk protein in lactating dairy cows
}

\author{
C. Lee, ${ }^{*}$ F. Giallongo, ${ }^{*}$ A. N. Hristov, ${ }^{* 1}$ H. Lapierre, $†$ T. W. Cassidy, ${ }^{*}$ K. S. Heyler, ${ }^{*}$ G. A. Varga, ${ }^{*}$ and C. Parys \\ *Department of Animal Science, Pennsylvania State University, University Park 16802 \\ †Dairy and Swine Research and Development Centre, Agriculture and Agri-Food Canada, Sherbrooke, QC, Canada J1M 0C8 \\ ‡Evonik Industries AG, Hanau 63457, Germany
}

\begin{abstract}
This study investigated the effect of metabolizable protein (MP) supply and rumen-protected (RP) Lys and Met supplementation on productivity, nutrient digestibility, urinary $\mathrm{N}$ losses, apparent total-tract digestibility of dietary AA, and the efficiency of AA utilization for milk protein synthesis in dairy cows. The experiment was conducted with 8 ruminally cannulated Holstein cows in a replicated $4 \times 4$ Latin square design trial with 21-d periods. Treatments were (1) MP-adequate diet (AMP; MP balance of $-24 \mathrm{~g} / \mathrm{d}$ ); (2) MP-deficient diet (DMP; MP balance of $-281 \mathrm{~g} / \mathrm{d}$ ); (3) DMP supplemented with $100 \mathrm{~g}$ of RPLys/cow per day (estimated digestible Lys supply $=24 \mathrm{~g} / \mathrm{d}$; DMPL; MP balance of $-305 \mathrm{~g} / \mathrm{d}$ ); and (4) DMPL supplemented with $24 \mathrm{~g}$ of RPMet/cow per day (estimated digestible Met supply $=15 \mathrm{~g} / \mathrm{d}$; DMPLM; MP balance of $-256 \mathrm{~g} / \mathrm{d}$ ). Diet had no effect on total-tract nutrient digestibility, milk production, and milk composition, but the DMP diets decreased urinary $\mathrm{N}$ excretion and the ammonia emitting potential of manure. Plasma Met concentration was increased by DMPLM compared with AMP. Supplementation with RPLys had no effect on plasma Lys. Concentration of most AA in milk protein was increased or tended to be increased by DMPLM compared with DMPL. Except for the AA supplemented as RPAA (i.e., Met and Lys), apparent total-tract digestibility of all dietary AA was generally greater for the DMP diets and ranged from $33 \%$ (Arg, AMP diet) to $67 \%$ (Thr, DMPL diet). Apparent recovery of dietary AA in milk protein followed the same trends, being greater for the DMP diets than AMP and generally lower for Lys and Met with the RPAA-supplemented diets versus AMP and DMP. The RPAA were apparently not used for milk protein synthesis in the conditions of this experiment. The AA recoveries in milk protein varied from around 17\% (Ala)
\end{abstract}

Received June 17, 2014

Accepted November 17, 2014.

${ }^{1}$ Corresponding author: anh13@psu.edu to $70 \%$ (Pro). Milk protein recoveries of essential AA (EAA) were around $54 \%$ for the DMP diet and $49 \%$ for AMP. The estimated efficiency of utilization of digestible EAA for milk protein synthesis was generally greater for the DMP diets compared with AMP. In this trial, blood plasma Lys and Met were labeled by abomasal pulsedose of ${ }^{15} \mathrm{~N}$-Lys and ${ }^{13} \mathrm{C}$-Met (respectively). Analysis of the ${ }^{15} \mathrm{~N}$-Lys and ${ }^{13} \mathrm{C}$-Met decay curves in plasma indicated trends for a faster extraction of Lys and Met from plasma for the MP-deficient diets, compared with AMP. Overall, this study confirmed conclusions from previous analyses that the efficiency of utilization of dietary EAA will increase with decreasing MP-AA supply.

Key words: dietary protein, rumen-protected methionine, rumen-protected lysine, amino acid utilization, dairy cow

\section{INTRODUCTION}

Protein nutrition of the dairy cow is 2-dimensional with dietary proteins providing $\mathrm{N}$ for microbial protein synthesis in the rumen and then complementing microbial protein to supply AA for maintenance, growth, reproduction, and milk protein synthesis by the cow. Although the rumen (and the ruminant animal) can function on NPN alone (Virtanen, 1966), adequate supply of essential and limiting AA is critical for maintaining the high milk production of modern dairy cows (NRC, 2001). Production responses in earlier studies and AA concentrations in plasma, rumen microbial, milk, and common feedstuff proteins have identified Met, Lys, and His as most limiting AA in dairy cows in various intensive production systems (Griel et al., 1968; Broderick et al., 1974; Vanhatalo et al., 1999; Schwab et al., 2005). Dietary supplementation of rumen-protected (RP) forms of Met and Lys has been extensively studied, but production responses have not been consistent (Patton, 2010; Robinson, 2010), perhaps partially due to oversupply of MP and AA in some of the studies used in these meta-analyses.

Several analyses concluded that the transfer efficiency of MP and individual AA into milk protein is not 
constant and decreases with increasing supply (Doepel et al., 2004; Metcalf et al., 2008). Similar trends have been reported for supplemental RPMet and RPLys by Vyas and Erdman (2009). In that study, the authors estimated sharp decreases in the marginal efficiency of Met and Lys utilization for milk protein synthesis with increasing AA supply. A recent meta-analysis by Martineau et al. (2014) concluded that the efficiency of transfer of feed $\mathrm{N}$ into AA-N appearing in portal circulation is increased when dietary protein is in short supply. An analysis of a data set from trials in which cows were fed at or below MP requirements showed apparent efficiency of utilization of predicted (NRC, 2001) digestible Met, Lys, and His supplied at the duodenum for synthesis of milk AA of $72 \pm 0.72,61 \pm$ 0.65 , and $61 \pm 0.68 \%$, respectively, once requirements for maintenance are removed from AA supply (A. N. Hristov, unpublished data). The conversion coefficients, however, varied largely among individual cows and were negatively correlated with MP supply $(\mathrm{r}=-0.37$ to -0.46). Although the efficiencies calculated using this approach are likely overestimated due in part to overestimation of maintenance AA requirements by NRC (2001), particularly metabolic fecal protein (MFP; Ouellet et al., 2010; Arriola Apelo et al., 2014), they are reflective of the negative relationship between efficiency of utilization and supply of MP or individual AA. In the meta-analysis of Doepel et al. (2004), the efficiency of utilization of available Lys and Met for milk AA synthesis was $90 \%$ at $50 \%$ of optimum AA supply and decreased to $60 \%$ at $125 \%$ of optimum supply. Thus, it is apparent that the efficiency of utilization of MP-AA for milk protein synthesis in dairy cows is not constant (as assumed by NRC, 2001), but depends on supply and demand. Apart from the modeling data mentioned above, experimental evidence in support of this concept was observed by Raggio et al. (2004) and Lemosquet et al. (2010), where the nonproductive removal of AA across tissues increased with AA supply.

Therefore, the main objective of this experiment was to estimate apparent efficiencies of utilization of dietary AA for milk protein synthesis in dairy cows fed MP-adequate or MP-deficient diets, according to NRC (2001). Our hypothesis was that increased AA supply would decrease the apparent efficiencies of use of dietary and digestible AA for milk protein synthesis. A secondary objective was to evaluate the production effects and estimate the utilization efficiency of use for milk protein synthesis of RPMet and RPLys supplemented to an MP-deficient diet.

\section{MATERIALS AND METHODS}

Animals involved in these experiments were cared for according to the guidelines of the Pennsylvania State
University Animal Care and Use Committee. The committee reviewed and approved the experiment and all procedures carried out in the study.

\section{Animals and Experimental Design}

This experiment used 8 multiparous $(2.8, \mathrm{SD}=0.7$ lactations) Holstein dairy cows in a replicated $4 \times 4$ Latin square design, balanced for residual effects, with 2 concurrent squares and four 21-d periods. At the beginning of the trial, BW of the cows averaged 684 $\mathrm{kg}(\mathrm{SD}=68)$, DIM, $102 \mathrm{~d}(\mathrm{SD}=28)$, and milk yield, $43 \mathrm{~kg} / \mathrm{d}(\mathrm{SD}=5.3)$. For the first $12 \mathrm{~d}$ of each experimental period, cows were housed in the tie-stall facility of Pennsylvania State University's Dairy Center. During the last $9 \mathrm{~d}$ of each period, cows were moved to metabolic stalls, in which total fecal and urine collections were conducted. All cows were fitted with 10-cm ruminal cannulas (Bar Diamond Inc., Parma, ID) and randomly assigned to one of the following treatments: (1) MP-adequate diet (AMP; MP balance of $-24 \mathrm{~g} / \mathrm{d}$ ); (2) MP-deficient diet (DMP; MP balance of -281 $\mathrm{g} / \mathrm{d})$; (3) DMP supplemented with $100 \mathrm{~g}$ of RPLys/cow per day (DMPL; MP balance of $-305 \mathrm{~g} / \mathrm{d}$ ); and (4) DMPL supplemented with $24 \mathrm{~g}$ of RPMet/cow per day (DMPLM; MP balance of $-256 \mathrm{~g} / \mathrm{d}$ ). The MP balance was estimated based on NRC (2001) requirements at treatment average DM intake, milk yield, and milk composition measured during the trial and nutrient composition of the diets (Table 1). AminoShure-L (Balchem Corporation, New Hampton, NY) and Mepron (Evonik Industries AG, Hanau, Germany) were used as sources of RPLys and RPMet, respectively. The application rates of RPLys (100 g/animal per day) and RPMet (24 g/animal per day) were designed to meet the requirements of digestible Lys (dLys) and Met (dMet) of the cows, assumed at 6.6 and $2.2 \%$ of the MP requirements, respectively (Schwab et al., 2005). The supply of dLys and dMet from AminoShure-L and Mepron were estimated at 24 and $15 \mathrm{~g} / \mathrm{cow}$ per day using the manufacturers' data (AminoShure-L, 38\% Lys and $64 \%$ bioavailability; and Mepron, $85 \%$ Met and $72 \%$ bioavailability). Diets were fed as TMR once daily at $0800 \mathrm{~h}$ targeting 5 to $10 \%$ refusals. The RPLys and RPMet were top-dressed, mixed with a small portion of the freshly delivered TMR.

\section{Sampling and Measurements}

During the entire experiment, TMR offered and refusals were recorded daily. Samples of TMR, refusal, and individual feed ingredients were collected twice weekly. Samples were dried for $48 \mathrm{~h}$ at $65^{\circ} \mathrm{C}$ in a forced-air oven and ground in a Wiley Mill (A. H. Thomas Co., 
Philadelphia, PA) through a 1-mm sieve for analysis. Composite (equal weight basis) samples of individual feed ingredients were submitted to Cumberland Valley Analytical Services (Maugansville, MD) for wet chemistry analyses of $\mathrm{CP}, \mathrm{NDF}, \mathrm{ADF}, \mathrm{Ca}$, and $\mathrm{P}$ and estimated NFC (details at: http://www.foragelab.com/ Resources/Lab-Procedures, accessed January 2, 2014; AOAC International, 2000, procedures 990.03, 973.18, and 985.01 for CP, $\mathrm{ADF}$, and $\mathrm{Ca}$ and $\mathrm{P}$, respectively, and Van Soest et al., 1991, for NDF). Diet composition was estimated based on composition of individual feed ingredients and their inclusion in the TMR. Individual feed ingredients were also analyzed for AA by Evonik Industries AG (AOAC International, 1995; European Commission, 2009) and used to calculate AA intake, digestible AA flow, and AA balance. Performic acid oxidation was used for Met and Cys analysis. Cows were milked twice daily (around 0500 and $1700 \mathrm{~h}$ ) and milk yields of individual cows were recorded at each milking. Cows had continuous access to a water source.

Rumen samples were collected on d 14 of each experimental period. Whole ruminal contents were collected at $0,2,4,6$, and $8 \mathrm{~h}$ after feeding from the rumen ventral sac, atrium, and 2 samples from the feed mat. Samples were filtered through 2 layers of cheesecloth and the filtrate was immediately analyzed for $\mathrm{pH}(\mathrm{pH}$ meter 59000-60 pH Tester, Cole-Parmer Instrument Company, Vernon Hills, IL) and further processed for analyses of ammonia (Chaney and Marbach, 1962) and VFA (Yang and Varga, 1989).

On d 15 of each experimental period before feeding, $1 \mathrm{~g} /$ cow of ${ }^{15} \mathrm{~N}$-Lys (L-Lys $2 \mathrm{HCl}, \alpha^{-15} \mathrm{~N}, 95$ to 99 atom $\%^{15} \mathrm{~N}$; Cambridge Isotope Laboratories Inc., Andover, MA) and $1 \mathrm{~g} /$ cow of ${ }^{13} \mathrm{C}-$ Met (L-Met- $1-{ }^{13} \mathrm{C}$, 99 atom $\%{ }^{13} \mathrm{C}$; Isotec Inc., Miamisburg, $\mathrm{OH}$ ) were pulse-dosed into the abomasum of the cows, after approximately one-third of the rumen contents were removed using an infusion tube similar to the one described by Hristov et al. (1998) fitted with a 500-mL plastic bottle. The labeled AA were dissolved or suspended in $250 \mathrm{~mL}$ of saline solution $(9 \mathrm{~g} / \mathrm{L} \mathrm{NaCl}$ in distilled water) and infused into the abomasum in about $5 \mathrm{~min} / \mathrm{cow}$. Another $250 \mathrm{~mL}$ of saline solution were infused to wash out any AA remaining in the infusion tube. Blood samples were collected from the tail vein or artery by venipuncture in heparinized tubes at $0,0.5,1,2$ (experimental periods 1,2 , and 3 ) and $0,0.5,1,2,3$, and $4 \mathrm{~h}$ (experimental period 4 only) postdose. Plasma was isolated by centrifugation at $1,500 \times g$ for $15 \mathrm{~min}$ and stored frozen at $-20{ }^{\circ} \mathrm{C}$ for analysis of ${ }^{15} \mathrm{~N}$-Lys and ${ }^{13} \mathrm{C}$-Met enrichment. The isotopic enrichment (IE) of plasma Lys and Met were determined using a GC-MS system (model GC6890-MS5973, Agilent Technologies, Wilmington, DE) according to Calder and Smith (1988). Briefly, plasma Met were deproteinized with sulfosalicylic acid and derivatized with $\mathrm{N}$-(t-butyldimethysilyl)-N-methy ltrifluoroacetate:acetronile (1:1) to produce t-butyldimethylsilyl (tBDMS) derivatives and $\mathrm{m} / \mathrm{z}$ ions 320 and 321 were monitored to determine Met IE and $\mathrm{m} / \mathrm{z}$ ions 431 and 432 for Lys IE. To derive qualitative knowledge of the differences in isotope kinetics among diets, the treatment means of plasma ${ }^{15} \mathrm{~N}$-Lys and ${ }^{13} \mathrm{C}$-Met were fitted to a 3-parameter exponential decay equation $\left(\mathrm{R}^{2}\right.$ $>$ 0.99; SigmaPlot, Systat Software Inc., San Jose, CA) against time following the abomasal pulse-dose. The following equation was used: $f=y 0+a \times \exp (-b \times x)$, where $f$ is atom $\%$ excess $\left({ }^{15} \mathrm{~N}\right.$ for Lys and ${ }^{13} \mathrm{C}$ for Met), $y 0, a$, and $b$ are the regression parameters (horizontal and vertical asymptotes, as atom \% excess, and the decay rate, as atom $\%$ excess/h, respectively), and $x$ is time (h) after abomasal pulse-dose of the labeled AA.

Separate blood samples were collected on d 13 (1200 h) and 14 (0600 and $1800 \mathrm{~h})$ of each experimental period. Plasma was isolated as described above, composited on an equal volume basis per cow and period and analyzed for AA by Evonik Industries AG and for urea-N (Stanbio Urea-N Kit 580, Stanbio Laboratory Inc., San Antonio, TX).

Total fecal and urine collections were conducted for 5 d (d 17 to d 21 of each experimental period), following $4 \mathrm{~d}$ of adaptation to the stalls. Feces were collected in metal containers positioned behind the metabolic units and transferred, weighed, and sampled once daily (at approximately $0600 \mathrm{~h}$ ). Aliquots of the fresh feces were stored frozen at $-20^{\circ} \mathrm{C}$ and later thawed and composited on a weight basis by cow and period. The composite wet samples were used for analysis of the ammonia-emitting potential (AEP) of manure (see below). Aliquots of the fecal samples were dried at $65^{\circ} \mathrm{C}$ in a forced-air oven for $48 \mathrm{~h}$ and then composited on a dry weight basis by cow and period. The composite fecal samples were analyzed for DM, OM, CP, NDF, ADF, and AA. Dry matter and OM of feces were determined following the procedure of AOAC International (2000), and NDF and ADF were analyzed using the Ankom A200 fiber analyzer (Ankom Technology, Macedon, NY) based on the procedure described by Van Soest et al. (1991) with amylase and sodium sulfide used in the NDF analysis. Aliquots of the composite fecal samples were pulverized using a Mixer Mill MM 200 (Retsch GmbH, Haan, Germany) for N analysis using a Costech ECS $4010 \mathrm{C} / \mathrm{N} / \mathrm{S}$ elemental analyzer (Costech Analytical Technologies Inc., Valencia, CA), and CP was calculated by multiplying by 6.25 . Feces were analyzed for AA by Evonik Industries AG as described above.

Urine was collected through urinary catheters as described by Hristov et al. (2010) into containers containing $2 \mathrm{~L}$ of $2 \mathrm{M}$ sulfuric acid, which maintained $\mathrm{pH}$ of 
Table 1. Ingredient and chemical composition of the diets fed in the experiment

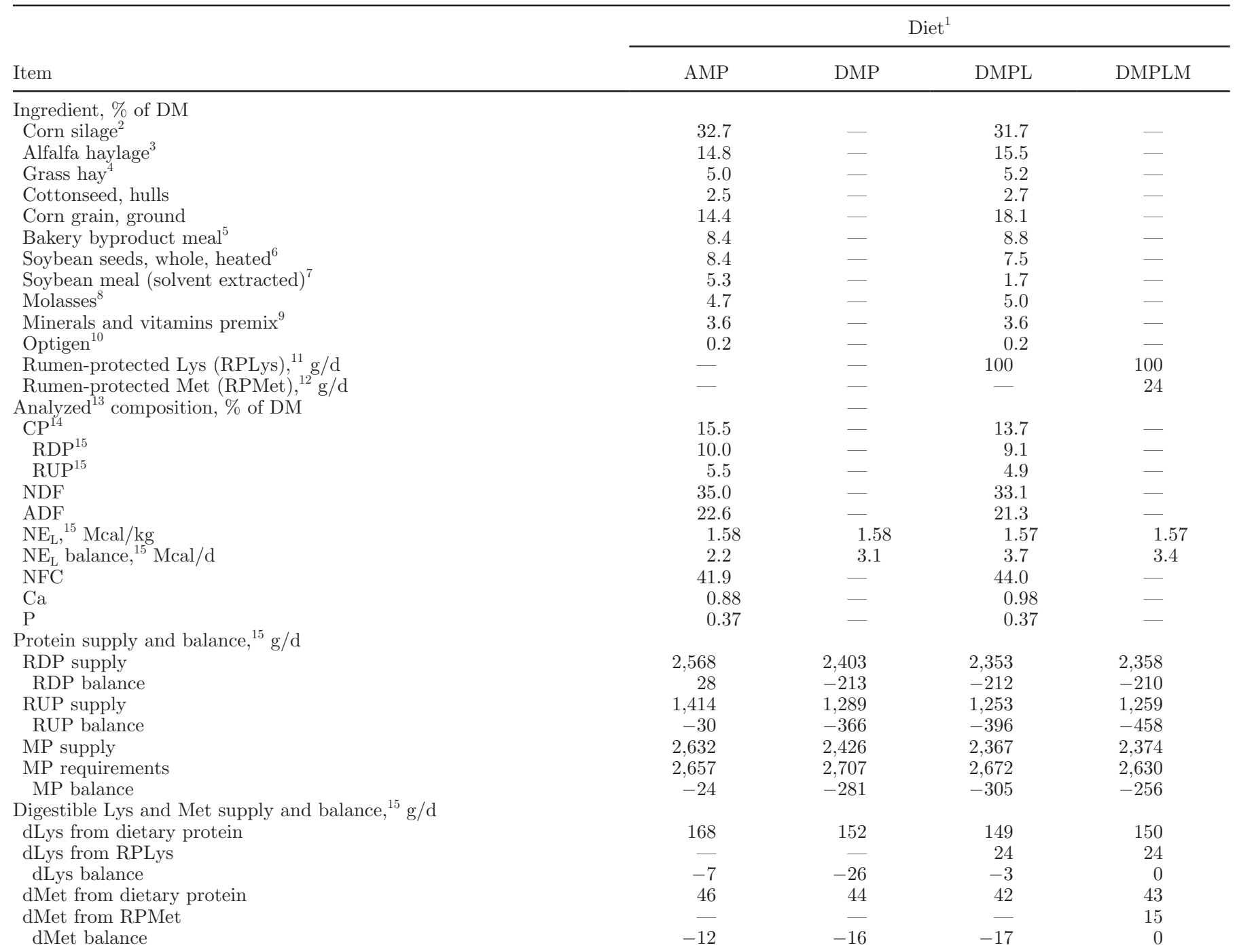

${ }^{1} \mathrm{AMP}=$ diet adequate in MP; DMP = diet deficient in MP; DMPL = diet deficient in MP supplemented with RPLys (AminoShure-L); DMPLM = diet deficient in MP supplemented with AminoShure-L and RPMet (Mepron). Feed ingredient and chemical composition of DMP, DMPL, and DMPLM diets were identical unless noted otherwise.

${ }^{2}$ Corn silage was $37.5 \% \mathrm{DM}$ and contained (DM basis): $41.7 \% \mathrm{NDF}$ and $8.1 \% \mathrm{CP}$.

${ }^{3}$ Alfalfa haylage was $35.1 \% \mathrm{DM}$ and contained (DM basis): $44.4 \% \mathrm{NDF}$ and $18.6 \% \mathrm{CP}$.

${ }^{4}$ Grass hay was $88.3 \% \mathrm{DM}$ and contained (DM basis): $75.5 \% \mathrm{NDF}$ and $7.5 \% \mathrm{CP}$.

${ }^{5}$ From Bakery Feeds Inc. (Honey Brook, PA); contained (DM basis): $14.1 \%$ CP and $13.5 \%$ NDF.

${ }^{6}$ Contained $46.9 \%$ CP (DM basis).

${ }^{7}$ Contained $53.8 \%$ CP (DM basis).

${ }^{8}$ From Westway Feed Products (Tomball, TX); contained (DM basis): $3.9 \% \mathrm{CP}$ and $66 \%$ total sugar.

${ }^{9}$ The premix contained (\%, as-is basis): trace mineral mix, 0.86; $\mathrm{MgO}(56 \% \mathrm{Mg}), 8.0 ; \mathrm{NaCl}, 6.4 ;$ vitamin ADE premix, 0.48; limestone, 37.2; selenium premix, 0.07; and dry corn distillers grains with solubles, 46.7. Ca, 14.1\%; P, 0.39\%; Mg, 4.59\%; K, 0.44\%; S, 0.39\%; Se, 6.91 mg/kg; $\mathrm{Cu}, 362 \mathrm{mg} / \mathrm{kg}$; Zn, $1085 \mathrm{mg} / \mathrm{kg} ; \mathrm{Fe}, 186 \mathrm{mg} / \mathrm{kg}$, vitamin A, 276,717 IU/kg; vitamin D, 75,000 IU/kg and vitamin E, 1,983 IU/kg.

${ }^{10}$ Slow-release urea (Alltech, Inc., Nicholasville, KY).

${ }^{11}$ AminoShure-L was a source of RPLys (Balchem Corporation, New Hampton, NY).

${ }^{12}$ Mepron was a source of RPMet (Evonik Industries AG, Hanau, Germany).

${ }^{13}$ Unless indicated otherwise, TMR composition was estimated based on composition of individual feed ingredients (Cumberland Valley Analytical Services; Maugansville, MD) and their inclusion in the TMR.

${ }^{14}$ Crude protein content of the rumen-protected AA-supplemented diets, estimated based on feed ingredient composition, including RPAA, was 13.8 (DMPL) and $14.0 \%$ (DMPLM).

${ }^{15}$ Values were estimated using NRC (2001). Requirements, supply, and balance (supplied - required) were based on actual DMI, milk yield, milk composition, and BW of the cows throughout the trial; digestible Lys (dLys) and digestible Met (dMet) supply from the diets were estimated using NRC (2001); dLys and dMet from AminoShure-L and Mepron were estimated from Lys and Met content and bioavailability data provided by the manufacturer: $38 \%$ Lys, $64 \%$ bioavailability and $85 \%$ Met, $72 \%$ bioavailability (respectively). Requirements of dLys and dMet were calculated as 6.6 and $2.2 \%$ (respectively) of MP requirements. 
the urine $<3.0$. The acidified urine was processed once daily as for the feces. Aliquots were diluted 1:10 with distilled water, composited on a volume basis by cow and period, and stored frozen at $-20^{\circ} \mathrm{C}$ until analyzed for N, allantoin (Chen, 1989), uric acid (Stanbio Uric Acid Kit 1051, Stanbio Laboratory Inc.), and urea-N (UUN; Stanbio Urea-N Kit 580, Stanbio Laboratory Inc.). Nitrogen was analyzed on freeze-dried urine samples using Costech ECS 4010 C/N/S elemental analyzer. Random urine samples were also analyzed for AA (Evonik Industries AG), but no detectable concentrations were found. Unacidified aliquots of the urine were collected daily directly from the urinary catheters, composited on a volume basis per animal and period, and stored frozen at $-20^{\circ} \mathrm{C}$ for later analysis of the AEP of manure.

The AEP of manure was analyzed using a steadystate flux chamber system (Wheeler et al., 2007) as described by Lee et al. (2012a). Samples were incubated for $24 \mathrm{~h}$ at room temperature $\left(25^{\circ} \mathrm{C}\right)$.

Milk samples were collected at 2 consecutive milkings (p.m. and a.m.) and 2 consecutive days during each experimental period. Samples were placed in tubes containing 2-bromo-2-nitropropane-1,3-diol for analysis of milk fat, true protein, lactose, and MUN (Pennsylvania DHIA, University Park, PA) using infrared spectroscopy (MilkoScan 4000; Foss Electric, Hillerød, Denmark). Samples were composited on a volume basis and per cow and period, and milk protein was isolated (Hristov and Ropp, 2003), freeze-dried, and analyzed for AA by Evonik Industries AG as described above.

Cow BW were recorded throughout the trial using AfiFarm 3.04E scale system (S.A.E. Afikim, Rehovot, Israel) while cows exited the milk parlor.

Intake of AA was estimated based on DMI, proportion of individual feed ingredients in TMR (DM basis), and AA analysis of the individual feed ingredients. Apparent total-tract digestibility of nutrients was determined based on nutrient intake and nutrient excretion in feces (Schneider and Flatt, 1975). Apparent totaltract digestibility (\%) of dietary AA was calculated as [(AA intake, $\mathrm{g} / \mathrm{d}-\mathrm{AA}$ in feces, $\mathrm{g} / \mathrm{d}) \div \mathrm{AA}$ intake, $\mathrm{g} / \mathrm{d}] \times 100$. The recovery $(\%)$ of dietary AA in milk true protein was calculated as (AA secretion in milk true protein, $\mathrm{g} / \mathrm{d} \div \mathrm{AA}$ intake, $\mathrm{g} / \mathrm{d}) \times 100$. The apparent efficiency of utilization (\%) of predicted digestible EAA (dEAA) (NRC, 2001) for milk protein secretion was calculated as: EAA secreted in milk true protein $\div$ [dEAA flow - estimated EAA requirements for maintenance] $\} \times 100$, all expressed in $\mathrm{g} / \mathrm{d}$. The dEAA flow was calculated using NRC (2001) individually for each cow based on EAA analysis of the feed ingredients and the cow's BW, milk production and composition, and DMI. Maintenance requirements for EAA were estimated based on MP requirements for maintenance (NRC, 2001) and EAA composition of MP. Maintenance requirements for EAA include requirements for scurf protein, urinary protein, MFP, and endogenous protein (NRC, 2001). Essential AA composition of scurf protein was that used by the Cornell Net Carbohydrate and Protein System (O'Connor et al., 1993), which was based on EAA composition of keratin (Block and Bolling, 1951). The EAA composition of tissue protein was used for estimating the requirements for urinary protein (O'Connor et al., 1993) and the EAA composition of endogenous protein in pigs fed a protein-free diet supplemented with AA (de Lange et al., 1989) was used to calculate both MFP and duodenal endogenous EAA requirements. Requirements of MP for MFP were calculated based on the NRC (2001) equation: $\{(\mathrm{DMI}$, $\mathrm{kg} / \mathrm{d} \times 30)-0.50 \times[($ bacterial $\mathrm{MP} \div 0.80)-$ bacterial $\mathrm{MP})]\}$. Bacterial MP production $(\mathrm{g} / \mathrm{d})$ was as predicted by NRC (2001).

\section{Statistical Analysis}

All data were analyzed using PROC MIXED of SAS (2003, SAS Inst. Inc., Cary, NC). All data, except rumen fermentation and plasma ${ }^{15} \mathrm{~N}-\mathrm{Lys}$ and ${ }^{13} \mathrm{C}$-Met, were analyzed by ANOVA Latin square with treatment, square, and period in the model with the error term assumed to be normally distributed with mean $=0$ and constant variance. Cow within square was the random effect, whereas all others were fixed. Rumen fermentation and plasma ${ }^{15} \mathrm{~N}$-Lys and ${ }^{13} \mathrm{C}$-Met data were analyzed as repeated measures assuming an autoregressive(1) covariance structure with treatment, square, period, sampling time point, and treatment $\times$ sampling time point interaction in the model. The error term assumed to be normally distributed with mean $=$ 0 and constant variance.

Significant differences were declared at $P \leq 0.05$. Differences at $0.05<P \leq 0.10$ were considered as a trend toward significance. When the main effect of treatment was significant, means were separated using the TukeyKramer option of PROC MIXED. Means are presented, unless indicated otherwise, as LSM.

\section{RESULTS}

The diets fed in this trial were similar to the diet fed in a concomitant completely randomized block design trial by Lee et al. (2012b). The AMP diet supplied MP at about $1 \%$ below requirements (according to NRC, 2001), based on AA analysis of all feed ingredients, actual milk yield and milk composition, and DMI during the trial (Table 1). The DMP diets were from 256 to $305 \mathrm{~g} / \mathrm{d}$ (10 to $11 \%$ ) deficient in MP. According to 
Table 2. Effect of MP supply and rumen-protected (RP) AA supplementation on nutrient intake and totaltract apparent digestibility in dairy cows

\begin{tabular}{|c|c|c|c|c|c|c|}
\hline \multirow[b]{2}{*}{ Item } & \multicolumn{4}{|c|}{$\operatorname{Diet}^{1,2}$} & \multirow[b]{2}{*}{ SEM } & \multirow[b]{2}{*}{$P$-value ${ }^{3}$} \\
\hline & AMP & DMP & DMPL & DMPLM & & \\
\hline \multicolumn{7}{|c|}{ Nutrient intake, $\mathrm{kg} / \mathrm{d}$} \\
\hline $\mathrm{DM}^{4}$ & 25.9 & 25.8 & 26.5 & 26.4 & 0.87 & 0.55 \\
\hline OM & 24.2 & 24.0 & 24.7 & 24.6 & 0.81 & 0.59 \\
\hline $\mathrm{NDF}$ & 7.7 & 7.7 & 7.9 & 7.9 & 0.26 & 0.36 \\
\hline $\mathrm{ADF}$ & 4.9 & 4.9 & 5.0 & 5.0 & 0.16 & 0.40 \\
\hline $\mathrm{CP}$ & $3.9^{\mathrm{a}}$ & $3.5^{\mathrm{b}}$ & $3.6^{\mathrm{b}}$ & $3.6^{\mathrm{b}}$ & 0.12 & 0.001 \\
\hline \multicolumn{7}{|c|}{ Apparent digestibility, \% } \\
\hline $\mathrm{DM}$ & 61.5 & 60.9 & 60.0 & 61.8 & 0.75 & 0.14 \\
\hline $\mathrm{OM}$ & 62.8 & 62.0 & 61.2 & 63.1 & 0.80 & 0.13 \\
\hline $\mathrm{NDF}$ & 30.7 & 29.0 & 29.7 & 32.5 & 1.51 & 0.40 \\
\hline $\mathrm{ADF}$ & $22.5^{\mathrm{ab}}$ & $21.8^{\mathrm{b}}$ & $23.2^{\mathrm{ab}}$ & $26.2^{\mathrm{a}}$ & 1.21 & 0.05 \\
\hline $\mathrm{CP}$ & 59.4 & 56.0 & 54.3 & 55.8 & 2.33 & 0.11 \\
\hline
\end{tabular}

${ }_{\mathrm{a}, \mathrm{b}}$ Within a row, means without a common superscript letter $\operatorname{differ}(P \leq 0.05)$.

${ }^{1} \mathrm{AMP}=$ diet adequate in MP; DMP = diet deficient in MP; DMPL = diet deficient in MP supplemented with RPLys (AminoShure-L, Balchem Corporation, New Hampton, NY); DMPLM = diet deficient in MP supplemented with AminoShure-L and RPMet (Mepron, Evonik Industries AG, Hanau, Germany).

${ }^{2}$ Least squares means; $\mathrm{n}=29$ (represents number of observations used in the statistical analysis). Largest SEM published.

${ }^{3} P$-values for the main effect of treatment.

${ }^{4}$ DMI during total fecal and urine collection periods.

NRC (2001), the DMP diets were about $8 \%$ deficient in RDP and 22 to $27 \%$ deficient in RUP. The positive control diet, AMP, was about $4 \%$ deficient in dLys and about $21 \%$ deficient in dMet, based on the assumption that dLys requirement is $6.6 \%$ and dMet requirement is $2.2 \%$ of MP (Schwab et al., 2005). The negative control diet (DMP) was about 15\% deficient in dLys and about $27 \%$ deficient in dMet. Using the manufacturer's data, the RPLys-supplemented diets were about $2 \%$ deficient (DMPL) or met (DMPLM) dLys requirements. The RPMet-supplemented diet (DMPLM) met dMet requirements, according to NRC (2001).

Intakes of organic matter, NDF, and ADF were similar among diets and intake of $\mathrm{CP}$ was lower $(P=0.001)$ for the DMP diets versus AMP (Table 2). Apparent total-tract digestibility of DM, OM, and NDF were not different $(P \geq 0.13)$ among diets, but ADF digestibility was higher $(P=0.05)$ for DMPLM versus DMP and the apparent digestibility of $\mathrm{CP}$ tended to be numerically lower $(P=0.11)$ for the DMP diets versus AMP.

Nitrogen intake was about $9 \%$ lower $(P=0.001)$ for the DMP diets compared with AMP (Table 3). Milk protein $\mathrm{N}$ secretion and fecal $\mathrm{N}$ excretion were not different among diets, but as expected, urinary N, UUN, and fecal plus urinary $\mathrm{N}$ excretions were lower $(P=$ $0.006,<0.001$, and 0.02 , respectively) for the DMP diets versus AMP. Urinary urea-N excretion tended to be greater $(P=0.09)$ for the RPAA-supplemented diets compared with DMP. As a proportion of N intake, total $\mathrm{N}$ excreted in feces and secreted in milk protein were not different among diets. As a proportion of $\mathrm{N}$ intake, urinary $\mathrm{N}$ excretion was lower $(P=0.03)$ for DMP and DMPL (and numerically lower for DMPLM; $P=0.12$ ) versus AMP. Urinary allantoin and total purine derivatives (allantoin plus uric acid) excretion tended to be 7 to $8 \%$ lower $(P=0.06$ to 0.08$)$ for DMP and DMPLM versus AMP and DMPL. Plasma urea-N concentration was on average $23 \%$ lower $(P=0.03)$ for DMP and DMPLM compared with AMP.

Most of the production parameters (DMI, milk yield, and milk composition) were not affected $(P \geq 0.24)$ by diet in this experiment (Table 4). Exceptions were 3.5\% FCM milk feed efficiency, which tended to be decreased $(P=0.09)$ by the DMP diets versus AMP, and concentration of MUN, which was on average $14 \%$ lower $(P$ $=0.03)$ or tended to be lower $(P=0.06$ to 0.12$)$ for the DMP diets. Milk $\mathrm{NE}_{\mathrm{L}}$ as proportion of $\mathrm{NE}_{\mathrm{L}}$ intake was not affected by diet. Body weight change tended to differ $(P=0.06)$ among diets, but these data should be interpreted with caution due to the short duration of the experimental periods in this study.

Most of the rumen fermentation variables measured in this experiment were also not affected $(P \geq 0.38)$ by diet, except that concentration of rumen ammonia was lower $(P=0.02)$ or tended to be lower $(P=0.07)$ and isobutyrate concentration tended to be lower $(P=$ 0.08) for the DMP diets compared with AMP (Table $5)$.

Concentrations of AA in blood plasma are shown in Table 6. Concentration of Met was increased $(P=$ 0.02 vs. AMP $)$ or tended to be increased $(P=0.11$ vs. DMP and DMPL) by RPMet supplementation 
Table 3. Effect of MP supply and rumen-protected (RP) AA supplementation on milk N secretion, $\mathrm{N}$ excretions, urinary purine derivative (PD) excretion, and plasma urea-N concentration in dairy cows

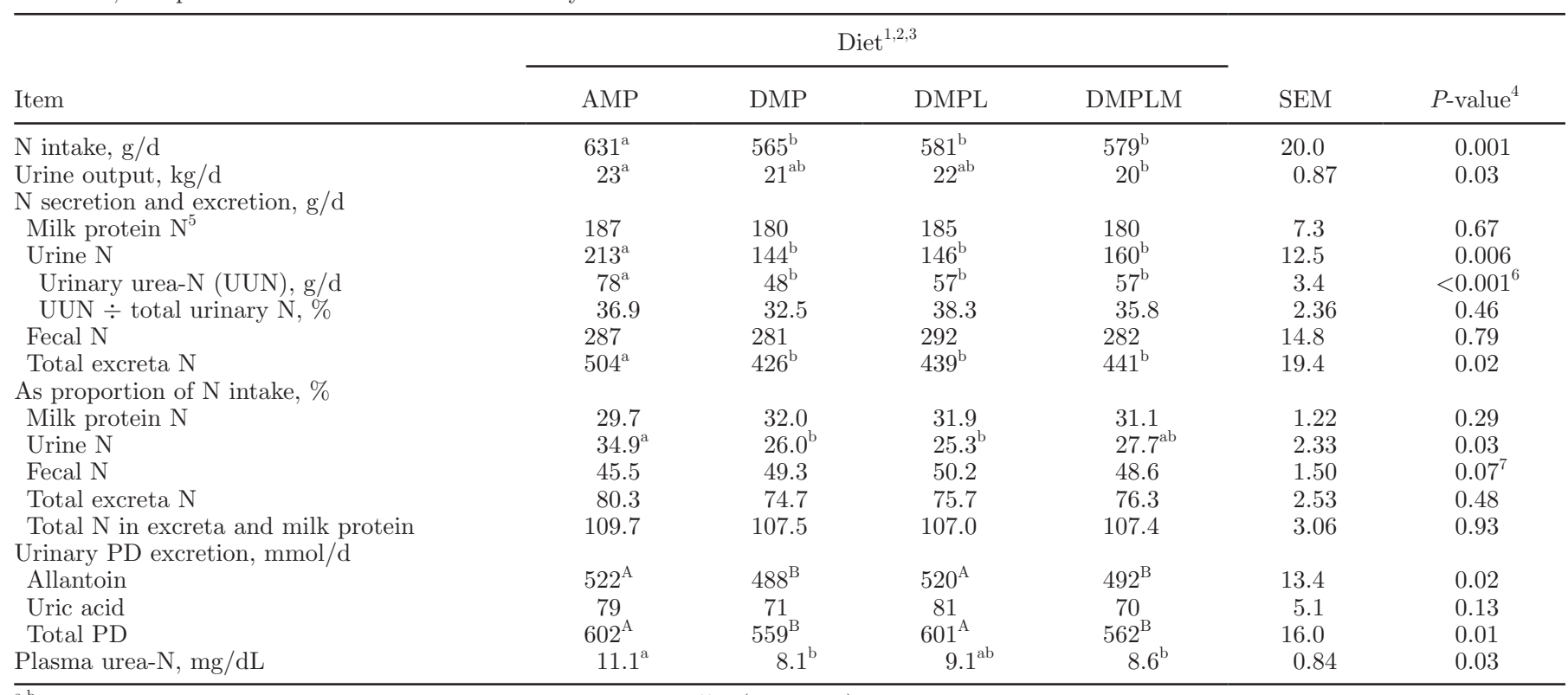

$\overline{\mathrm{a}, \mathrm{b}}$ Within a row, means without a common superscript letter differ $(P \leq 0.05)$.

${ }^{\mathrm{A}, \mathrm{B}}$ Within a row, means without a common superscript letter differ $(0.05 \leq P \leq 0.10)$.

${ }^{1} \mathrm{AMP}=$ diet adequate in MP; DMP $=$ diet deficient in MP; DMPL = diet deficient in MP supplemented with RPLys (AminoShure-L, Balchem Corporation, New Hampton, NY); DMPLM = diet deficient in MP supplemented with AminoShure-L and RPMet (Mepron, Evonik Industries AG, Hanau, Germany).

${ }^{2}$ Least squares means; $\mathrm{n}=29$ (represents number of observations used in the statistical analysis). Largest SEM published.

${ }^{3}$ Intake of $\mathrm{N}$ with the DMPL and DMPLM diet includes contribution by RPLys and RPMet.

${ }^{4} P$-values for the main effect of treatment.

${ }^{5}$ Milk true protein yield $\div 6.38$.

${ }^{6} \mathrm{DMP}$ versus DMPL and DMPLM, $P=0.09$.

${ }^{7} \mathrm{AMP}$ versus DMPL, $P=0.06$.

of the DMPLM diet. No other effects were observed, except trends for higher Gly, Ser, and total non-EAA concentrations $(P=0.06$ to 0.09$)$ with the DMP diets, compared with AMP.

Concentrations of AA in milk protein are shown in Table 7. Concentration of most AA was increased or tended to be increased for DMPLM versus the other diets. Concentration of Lys, for example, was on average about $2.8 \%$ higher for DMPLM versus DMPL $(P$ $=0.04)$ or tended to be higher versus AMP $(P=0.08)$ and DMP $(P=0.13)$. Concentration of Phe tended to be about $2.6 \%$ higher and that of Leu, $2.4 \%$ higher $(P$ $=0.10$ to 0.18$)$. Diet had no effect $(P \geq 0.34)$ on the amount of AA secreted daily in milk protein (Table 8 ).

Except for the AA supplemented as RPAA (i.e., Met and Lys) and Ala, apparent total-tract digestibility of all dietary AA was generally higher $(P \leq 0.04)$ for the RPAA-supplemented DMP diets compared with AMP and ranged from 33\% (Arg, AMP diet) to 67\% (Thr, DMPL diet; Table 9). Apparent digestibility of the EAA (with or without Met and Lys) varied around 47 to $48 \%$ for AMP and increased $(P \leq 0.04)$ to about $52 \%$ for the DMP diets (trends for DMP vs. AMP). Apparent recovery of dietary AA in milk protein followed the same trends as for AA digestibility, being lower $(P$ $<0.001$ ) for RPAA in the RPAA-supplemented diets versus AMP and DMP. Recoveries varied from around $17 \%$ (Ala) to $70 \%$ (Pro). Milk protein recovery of EAA was around $50 \%$ for the DMP diets and was lower or tended to be lower ( $P=0.02$ to 0.11$)$ for AMP compared with DMP or DMPLM.

The estimated efficiency of utilization of dEAA for milk protein synthesis was generally greater $(P \leq 0.003)$ for the DMP diets compared with AMP (Table 10). Exceptions were the efficiencies of utilization of dMet and dLys for the RPMet and RPLys-supplemented diets and Leu and EAA for DMPL (trends at $P=0.07$ ). The efficiency of utilization of dMet was the lowest $(P$ $<0.001)$ for DMPLM compared with all other diets. For dLys, the 2 RPLys-supplemented diets (DMPL and DMPLM) had efficiencies similar to AMP, but $19 \%$ lower $(P<0.001)$ than DMP. Of all analyzed EAA, the highest efficiency was for dMet (except DMPLM), dHis, and dPhe $(\geq 90 \%)$ and the lowest for dArg and 
Table 4. Effect of MP supply and rumen-protected (RP) AA supplementation on DMI, milk yield, milk composition, and BW change in dairy cows

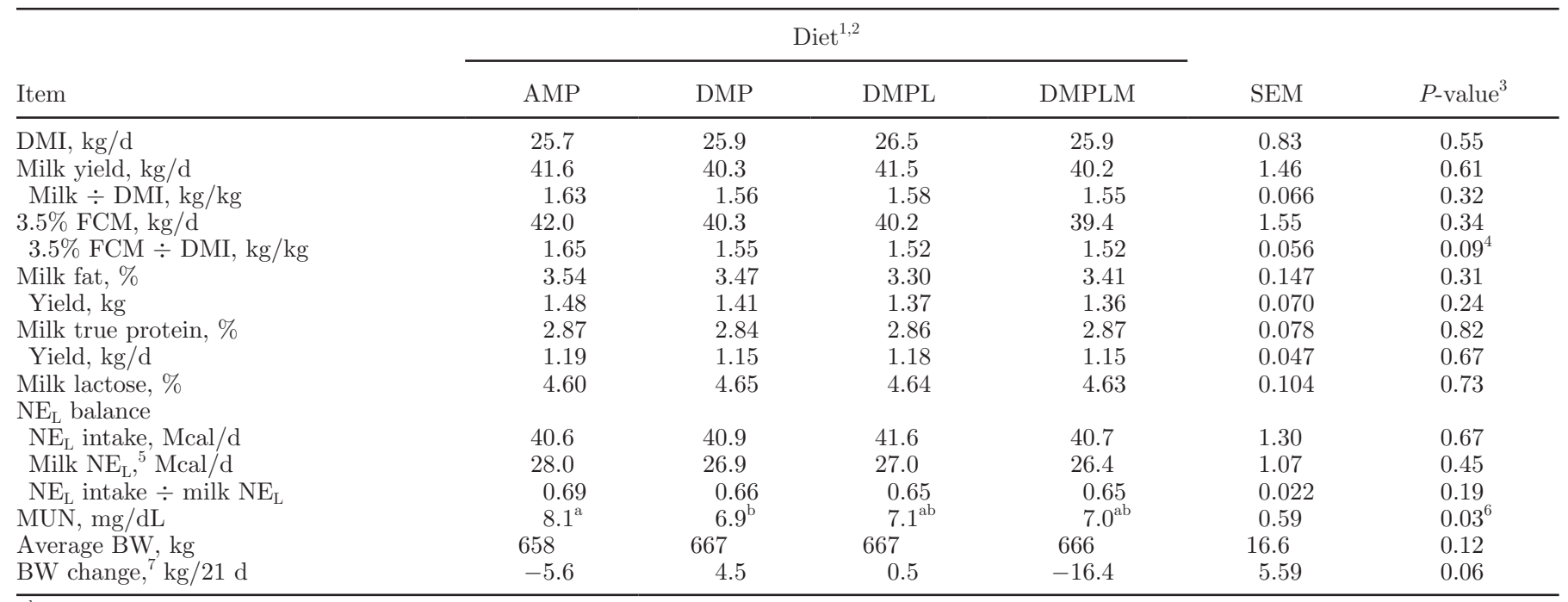

${ }_{\mathrm{a}, \mathrm{b}}$ Within a row, means without a common superscript letter differ $(P \leq 0.05)$.

${ }^{1} \mathrm{AMP}=$ diet adequate in MP; DMP $=$ diet deficient in MP; DMPL = diet deficient in MP supplemented with RPLys (AminoShure-L, Balchem Corporation, New Hampton, NY); DMPLM = diet deficient in MP supplemented with AminoShure-L and RPMet (Mepron, Evonik Industries AG, Hanau, Germany).

${ }^{2}$ Least squares means; $\mathrm{n}=29$ (represents number of observations used in the statistical analysis). Largest SEM published.

${ }^{3} P$-values for the main effect of treatment.

${ }^{4} \mathrm{AMP}$ versus DMPLM, $P=0.10$.

${ }^{5} \mathrm{Milk} \mathrm{NE}_{\mathrm{L}}(\mathrm{Mcal} / \mathrm{d})=\mathrm{kg}$ of milk $\times(0.0929 \times \%$ fat $+0.0563 \times \%$ true protein $+0.0395 \times \%$ lactose $)(\mathrm{NRC}, 2001)$.

${ }^{6} \mathrm{AMP}$ versus DMPLM, $P=0.06$.

${ }^{7}$ Average BW change during each 21-d period of the Latin square design trial.

the AMP diet (43\%). When Lys and Met were excluded from the total EAA, the average efficiency of utilization of EAA for the DMPL diet was $78.7 \%$ and for the DMPLM diet, $83.9 \%(\mathrm{SEM}=2.64, P=0.11)$.
The IE of plasma Lys and Met (respectively) after abomasal dosing of ${ }^{15} \mathrm{~N}$-Lys or ${ }^{13} \mathrm{C}$-Met followed different patterns (Figures 1 and 2, respectively). The IE of plasma Lys increased $(P<0.001)$ from the first

Table 5. Effect of MP supply and rumen-protected (RP) AA supplementation on ruminal fermentation in dairy cows

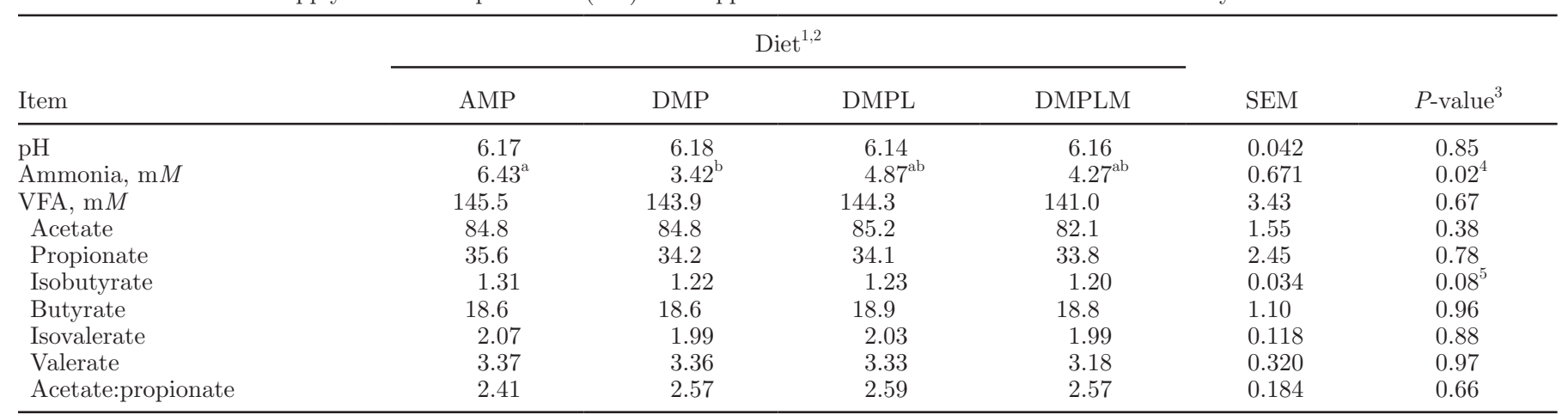

\footnotetext{
${ }^{a, b}$ Within a row, means without a common superscript letter differ $(P \leq 0.05)$.
}

${ }^{1} \mathrm{AMP}=$ diet adequate in MP; DMP $=$ diet deficient in MP; DMPL $=$ diet deficient in MP supplemented with RPLys (AminoShure-L, Balchem Corporation, New Hampton, NY); DMPLM = diet deficient in MP supplemented with AminoShure-L and RPMet (Mepron, Evonik Industries AG, Hanau, Germany).

${ }^{2}$ Least squares means; $\mathrm{n}=116$ (represents number of observations used in the statistical analysis). Largest SEM published.

${ }^{3} P$-values for the main effect of treatment. The effect of time of sampling (relative to feeding) was $P<0.05$ for most variables. No treatment $\times$ time of sampling interaction was observed for most variables $(P=0.22$ to 0.85$)$, except acetate:propionate, $P=0.02$.

${ }^{4} \mathrm{AMP}$ versus DMPLM, $P=0.07$.

${ }^{5} \mathrm{AMP}$ versus the DMP diets, $P=0.02$ to 0.06 . 
Table 6. Effect of MP supply and rumen-protected (RP) AA supplementation on blood plasma AA concentrations $(\mu M)$ in dairy cows

\begin{tabular}{|c|c|c|c|c|c|c|}
\hline \multirow[b]{2}{*}{ Item } & \multicolumn{4}{|c|}{$\operatorname{Diet}^{1,2}$} & \multirow[b]{2}{*}{ SEM } & \multirow[b]{2}{*}{$P$-value ${ }^{3}$} \\
\hline & $\mathrm{AMP}$ & DMP & DMPL & DMPLM & & \\
\hline Met & $12.6^{\mathrm{b}}$ & $14.5^{\mathrm{ab}}$ & $14.5^{\mathrm{ab}}$ & $19.0^{\mathrm{a}}$ & 1.46 & $0.02^{4}$ \\
\hline Lys & 50.9 & 52.2 & 60.7 & 58.7 & 3.68 & 0.20 \\
\hline Thr & 74.8 & 87.6 & 79.2 & 85.8 & 5.89 & 0.29 \\
\hline Arg & 58.9 & 58.2 & 62.8 & 62.4 & 4.19 & 0.78 \\
\hline Ile & 79.7 & 87.8 & 94.6 & 90.7 & 5.76 & 0.31 \\
\hline Leu & 101 & 110 & 115 & 114 & 6.8 & 0.45 \\
\hline Val & 172 & 176 & 186 & 184 & 10.7 & 0.78 \\
\hline His & 37.6 & 40.7 & 38.1 & 39.1 & 3.58 & 0.89 \\
\hline Phe & 34.0 & 38.1 & 38.0 & 37.9 & 2.07 & 0.28 \\
\hline Tyr & 44.3 & 50.0 & 49.2 & 49.2 & 3.68 & 0.46 \\
\hline Gly & 218 & 304 & 289 & 275 & 19.2 & $0.06^{5}$ \\
\hline Ser & 60.8 & 77.9 & 74.5 & 70.1 & 4.58 & $0.08^{6}$ \\
\hline Ala & 201 & 237 & 247 & 233 & 13.9 & 0.15 \\
\hline Tau & 29.4 & 33.3 & 32.5 & 33.9 & 2.10 & 0.39 \\
\hline Glu & 44.6 & 52.6 & 60.0 & 56.1 & 4.75 & 0.14 \\
\hline Asn & 30.5 & 38.4 & 36.6 & 36.8 & 2.67 & 0.15 \\
\hline Gln & 185 & 204 & 216 & 200 & 12.5 & 0.23 \\
\hline Total AA & 1,445 & 1,651 & 1,702 & 1,645 & 84.5 & 0.20 \\
\hline $\mathrm{EAA}^{7}$ & 624 & 663 & 692 & 691 & 38.1 & 0.56 \\
\hline EAA-LM $^{8}$ & 560 & 596 & 617 & 613 & 33.5 & 0.63 \\
\hline Non-EAA & 820 & 991 & 1,009 & 954 & 51.4 & $0.09^{9}$ \\
\hline
\end{tabular}

${ }^{\mathrm{a}, \mathrm{b}}$ Within a row, means without a common superscript letter differ $(P \leq 0.05)$.

${ }^{1} \mathrm{AMP}=$ diet adequate in MP; DMP $=$ diet deficient in MP; DMPL $=$ diet deficient in MP supplemented with RPLys (AminoShure-L, Balchem Corporation, New Hampton, NY); DMPLM = diet deficient in MP supplemented with AminoShure-L and RPMet (Mepron, Evonik Industries AG, Hanau, Germany).

${ }^{2}$ Least squares means; $\mathrm{n}=29$ (represents number of observations used in the statistical analysis). Largest SEM published.

${ }^{3} P$-values for the main effect of treatment.

${ }^{4}$ DMP and DMPL versus DMPLM, $P=0.11$.

${ }^{5}$ AMP versus DMP, $P=0.05$.

${ }^{6}$ AMP versus DMP, $P=0.07$.

${ }^{7}$ Essential AA without Trp.

${ }^{8} \mathrm{EAA}-($ Lys + Met).

${ }^{9} \mathrm{AMP}$ versus DMPL, $P=0.10$.

sampling at $30 \mathrm{~min}$ to $1 \mathrm{~h}$ postdose and steadily declined thereafter. Overall, variability in the data was large, diet had no effect $(P=0.64)$, and no diet $\times$ time postdose interaction $(P=0.49)$ was observed for ${ }^{15} \mathrm{~N}$-enrichment of plasma Lys. When analyzed by individual time points, however, DMP and DMPL tended to have higher $(P=0.10){ }^{15} \mathrm{~N}$-enrichment than AMP or DMPLM at 30 min (1.60 and 1.82 vs. 0.94 and 0.76 at $\%$ excess, respectively). The IE of plasma Met declined exponentially $(P<0.001)$ postdose with no effect of $\operatorname{diet}(P=0.79)$, or diet $\times$ time interaction $(P=0.49)$. The rates of disappearance of ${ }^{15} \mathrm{~N}$ from the plasma Lys pool were $\left(\mathrm{h}^{-1}\right.$; mean $\left.\pm \mathrm{SE}\right): 0.69 \pm 0.064$, $2.46 \pm 0.387,1.27 \pm 0.199$, and $1.18 \pm 0.043$ for AMP, DMP, DMPL, and DMPLM, respectively. The rates of disappearance of ${ }^{13} \mathrm{C}$ from the plasma Met pool were $1.29 \pm 0.184,2.76 \pm 0.215,2.63 \pm 0.124$, and $1.36 \pm$ 0.164 , respectively.

The cumulative ammonia emissions from reconstituted manure were on average $31 \%$ lower $(P=0.003)$ for the DMP diets, except DMPLM, compared with AMP (Figure 3). A trend $(P=0.07)$ was observed for lower cumulative emission for DMP versus DMPLM (a $19 \%$ difference).

\section{DISCUSSION}

As indicated earlier, the basal diet fed in the current experiment was similar to that fed in experiment 1 in the study by Lee et al. (2012b), justifying some comparison of the results from the 2 trials. The cows in the current trial had slightly higher DMI and higher milk production than the cows in Lee et al. (2012b). Feed efficiency of the control diet (AMP) was also slightly higher in the current trial, but feed efficiency for the RPAA-supplemented diets was similar between the studies. The MP balance for the DMP diets supplemented with RPAA averaged $-280 \mathrm{~g} / \mathrm{d}$ in the current study versus $-313 \mathrm{~g} / \mathrm{d}$ in Lee et al. (2012b); it is noted that the Lee et al. (2012b) study did not have 
Table 7. Effect of MP supply and rumen-protected (RP) AA supplementation on AA concentrations in milk $\mathrm{CP}$ (weight \%) in dairy cows

\begin{tabular}{|c|c|c|c|c|c|c|}
\hline \multirow[b]{2}{*}{ Item } & \multicolumn{4}{|c|}{$\operatorname{Diet}^{1,2}$} & \multirow[b]{2}{*}{ SEM } & \multirow[b]{2}{*}{$P$-value ${ }^{3}$} \\
\hline & AMP & DMP & DMPL & DMPLM & & \\
\hline Met & 2.50 & 2.50 & 2.50 & 2.58 & 0.031 & 0.09 \\
\hline Cys & 0.89 & 0.87 & 0.87 & 0.89 & 0.011 & $0.06^{4}$ \\
\hline Lys & $8.00^{\mathrm{ab}}$ & $8.03^{\mathrm{ab}}$ & $7.98^{\mathrm{b}}$ & $8.22^{\mathrm{a}}$ & 0.083 & $0.03^{5}$ \\
\hline Thr & $4.31^{\mathrm{ab}}$ & $4.29^{\mathrm{ab}}$ & $4.25^{\mathrm{b}}$ & $4.40^{\mathrm{a}}$ & 0.047 & 0.03 \\
\hline Arg & 3.38 & 3.37 & 3.34 & 3.44 & 0.031 & $0.07^{6}$ \\
\hline Ile & 5.13 & 5.16 & 5.12 & 5.26 & 0.054 & $0.05^{7}$ \\
\hline Leu & $9.65^{\mathrm{ab}}$ & $9.68^{\mathrm{ab}}$ & $9.61^{\mathrm{b}}$ & $9.88^{\mathrm{a}}$ & 0.075 & 0.04 \\
\hline Val & 6.22 & 6.26 & 6.22 & 6.38 & 0.060 & 0.09 \\
\hline His & 2.73 & 2.73 & 2.71 & 2.79 & 0.026 & 0.12 \\
\hline Phe & $4.94^{\mathrm{B}}$ & $4.95^{\mathrm{AB}}$ & $4.95^{\mathrm{B}}$ & $5.08^{\mathrm{A}}$ & 0.043 & 0.04 \\
\hline Gly & 1.86 & 1.86 & 1.86 & 1.90 & 0.019 & 0.08 \\
\hline Ser & 5.33 & 5.33 & 5.30 & 5.48 & 0.057 & 0.12 \\
\hline Pro & 9.92 & 10.0 & 10.0 & 10.2 & 0.112 & 0.36 \\
\hline Ala & $3.29^{\mathrm{ab}}$ & $3.28^{\mathrm{ab}}$ & $3.25^{\mathrm{b}}$ & $3.36^{\mathrm{a}}$ & 0.036 & 0.03 \\
\hline Asp & $7.74^{\mathrm{ab}}$ & $7.73^{\mathrm{ab}}$ & $7.67^{\mathrm{b}}$ & $7.89^{\mathrm{a}}$ & 0.063 & 0.03 \\
\hline Glu & 20.7 & 20.7 & 20.6 & 21.2 & 0.192 & $0.08^{8}$ \\
\hline $\mathrm{EAA}^{9}$ & $46.9^{\mathrm{ab}}$ & $47.0^{\mathrm{ab}}$ & $46.7^{\mathrm{b}}$ & $48.0^{\mathrm{a}}$ & 0.41 & $0.04^{10}$ \\
\hline NEAA & 49.7 & 49.8 & 49.6 & 50.9 & 0.43 & $0.09^{11}$ \\
\hline
\end{tabular}

${ }^{\mathrm{a}, \mathrm{b}}$ Within a row, means without a common superscript letter differ $(P \leq 0.05)$.

${ }^{\mathrm{A}, \mathrm{B}}$ Within a row, means without a common superscript letter differ $(0.05 \leq P \leq 0.10)$.

${ }^{1} \mathrm{AMP}=$ diet adequate in metabolizable protein $(\mathrm{MP}) ; \mathrm{DMP}=\operatorname{diet} \operatorname{deficient}$ in MP; DMPL $=\operatorname{diet}$ deficient in MP supplemented with RPLys (AminoShure-L, Balchem Corporation, New Hampton, NY); DMPLM = diet deficient in MP supplemented with AminoShure-L and RPMet (Mepron, Evonik Industries AG, Hanau, Germany).

${ }^{2}$ Least squares means; $\mathrm{n}=29$ (represents number of observations used in the statistical analysis). Largest SEM published.

${ }^{3} P$-values for the main effect of treatment.

${ }^{4}$ DMPL versus DMPLM, $P=0.07$.

${ }^{5}$ AMP versus DMPLM, $P=0.08$.

${ }^{6}$ DMPL versus DMPLM, $P=0.06$.

${ }^{7}$ DMPLM versus AMP and DMPL, $P=0.09$ and 0.07 , respectively.

${ }^{8}$ DMPL versus DMPLM, $P=0.10$.

${ }^{9}$ EAA without Trp.

${ }^{10}$ AMP versus DMPLM, $P=0.09$.

${ }^{11}$ DMPL versus DMPLM, $P=0.10$.

a negative control (i.e., a DMP diet without RPAA supplementation). With a difference of about $-30 \mathrm{~g} / \mathrm{d}$ in MP balance, the production responses to RPAA supplementation was similar between the 2 studies. In experiment 1 of Lee et al. (2012b), however, we observed a positive effect of RPMet on milk protein concentration, whereas this effect was not evident in the current study. Blood plasma Met concentration was increased by RPMet supplementation in the current study, but only numerical differences were observed in Lee et al. (2012b). Another important observation that needs to be pointed out is that in both trials DMI did not seem to be affected by treatment, but milk production was numerically decreased by the DMP diets (by about 1.1 to $1.4 \mathrm{~kg} / \mathrm{d}$, except DMPL). Lee et al. (2012b) reported a $42 \%$ decrease in blood plasma His concentration and a general trend for about $17 \%$ decrease in plasma EAA, whereas blood plasma EAA, including His, were not affected by MP deficiency in the current experiment.
Decreased ruminal ammonia concentration, excretion of urinary total N and UUN, MUN concentration, and ammonia emission from manure with decreasing dietary protein have been commonly reported in the literature (Paul et al., 1998; Kröber et al., 2000; Frank et al., 2002) and the current study is no exception. Unlike our previous trials (Lee et al., 2011, 2012b,c) and reports by others (Broderick, 2003; Olmos Colmenero and Broderick, 2006a), however, NDF digestibility was not decreased by the MP-deficient diets in the current experiment. Rumen fibrolytic bacteria require ammonia for growth (Atasoglu et al., 2001) and it is possible that ammonia supply from urea recycling was sufficient to sustain fiber degradability in the rumen for at least a part of the experimental periods in the current short-term study (although ammonia concentrations in ruminal fluid decreased by $47 \%$ with the DMP diet) in contrast to our observations from long-term trials (Lee et al., 2011, 2012b,c). 
Table 8. Effect of MP supply and rumen-protected (RP) AA supplementation on secretion of AA in milk protein $(\mathrm{g} / \mathrm{d})$ in dairy cows

\begin{tabular}{lcccccc}
\hline & \multicolumn{7}{c}{ Diet $^{1,2}$} & & \\
\cline { 2 - 4 } Item & AMP & DMP & DMPL & DMPLM & SEM & $P_{\text {-value }}{ }^{3}$ \\
\hline Met & 30.3 & 29.2 & 29.6 & 30.5 & 1.35 & 0.71 \\
Cys & 10.7 & 10.2 & 10.2 & 10.6 & 0.48 & 0.34 \\
Lys & 97.3 & 93.7 & 94.4 & 97.3 & 4.56 & 0.69 \\
Thr & 52.3 & 50.2 & 50.2 & 52.3 & 2.46 & 0.61 \\
Arg & 41.0 & 39.3 & 39.6 & 40.9 & 1.84 & 0.65 \\
Ile & 62.3 & 60.3 & 60.6 & 62.3 & 2.74 & 0.74 \\
Leu & 117 & 113 & 113 & 117 & 5.0 & 0.69 \\
Val & 75.4 & 73.0 & 73.5 & 75.6 & 3.26 & 0.75 \\
His & 33.1 & 31.8 & 32.0 & 33.0 & 1.36 & 0.70 \\
Phe & 60.0 & 57.8 & 58.3 & 60.3 & 2.60 & 0.70 \\
Gly & 22.6 & 21.8 & 21.9 & 22.6 & 0.92 & 0.60 \\
Ser & 64.7 & 62.2 & 62.5 & 64.9 & 2.95 & 0.69 \\
Pro & 120 & 117 & 118 & 121 & 5.21 & 0.89 \\
Ala & 39.9 & 38.3 & 38.4 & 39.8 & 1.71 & 0.57 \\
Asp & 93.3 & 89.1 & 89.9 & 88.2 & 6.14 & 0.85 \\
Glu & 251 & 242 & 243 & 251 & 11.2 & 0.73 \\
Total AA & 1,171 & 1,130 & 1,136 & 1,172 & 51.5 & 0.71 \\
EAA & 527 & 509 & 512 & 528 & 23.2 & 0.70 \\
EAA-LM & 400 & 386 & 388 & 401 & 17.3 & 0.70 \\
\hline
\end{tabular}

${ }^{1} \mathrm{AMP}=$ diet adequate in MP; DMP $=$ diet deficient in MP; DMPL $=$ diet deficient in MP supplemented with RPLys (AminoShure-L, Balchem Corporation, New Hampton, NY); DMPLM = diet deficient in MP supplemented with AminoShure-L and RPMet (Mepron, Evonik Industries AG, Hanau, Germany).

${ }^{2}$ Least squares means; $\mathrm{n}=29$ (represents number of observations used in the statistical analysis). Largest SEM published.

${ }^{3} P$-values for the main effect of treatment.

${ }^{4}$ Essential AA without Trp.

${ }^{5} \mathrm{EAA}-($ Lys + Met).

Overall, the production effects and environmental implications of dietary protein in dairy cows have been sufficiently covered in the literature (Kebreab et al., 2002; Ipharraguerre and Clark, 2005; Huhtanen and Hristov, 2009) and are not the main subject of this discussion. It is important to point out that the effect of dietary protein on animal productivity is not consistent and largely depends on the responses in DMI (Huhtanen and Hristov, 2009). In long-term trials (i.e., trials longer than the usual 3- to 4-wk periods of a changeover design experiment) we have observed trends for decreased DMI and decreased milk yield with diets that were 13 to $14 \%$ deficient in MP (Lee et al., 2011, 2012c), but the shorter-term, 10\% MP deficiency did not result in such effects in the current trial. Also, a MP deficiency of around 5\% did not trigger DMI and production responses in a recent 10-wk continuous design trial (Giallongo et al., 2014). It is not clear whether the lack of effect on DMI and milk production in the current trial is a result of the slightly higher MP intake relative to requirements, compared with Lee et al. (2011, 2012c), or of the experimental design of the trial (i.e., Latin square with 21-d experimental periods). The duration of the experiment may have an effect on the supply and availability of some EAA in this experiment when compared with Lee et al. (2012b), which, as discussed earlier, has been demonstrated for His, an AA with labile body reserve pools (hemoglobin and muscle carnosine; Lapierre et al., 2008). Another important variable that can be affected by MP supply, but cannot be reliably measured in short-term experiments is BW and BW change. For example, Giallongo et al. (2014) observed large differences in BW change in dairy cows fed a 5\% MP-deficient diet versus the MP-adequate or RPAA-supplemented DMP diets in a trial, in which treatment had no effect on DMI or milk production.

Other mechanisms may be responsible for the lack of effect of MP-deficiency on milk production in the current trial. Lee et al. (2012b) reported a substantial underprediction of milk production by the NRC (2001) model in cows fed MP-deficient diets. A recent meta-analysis by Martineau et al. (2014) suggested a more efficient utilization of dietary $\mathrm{N}$ in dairy cows fed diets with decreased protein content. Urea recycling is an $\mathrm{N}$ preservation mechanism in the ruminant animal that has been extensively discussed in the literature (Reynolds and Kristensen, 2008), but its importance in maintaining long-term productivity in animals fed protein-deficient diets is unknown. The ratio of protein entering the duodenum or omasum and dietary protein 
Table 9. Apparent, total-tract digestibility, and recovery in milk protein of dietary AA in dairy cows fed diets adequate or deficient in MP with or without supplementation with rumen-protected (RP) Lys and Met

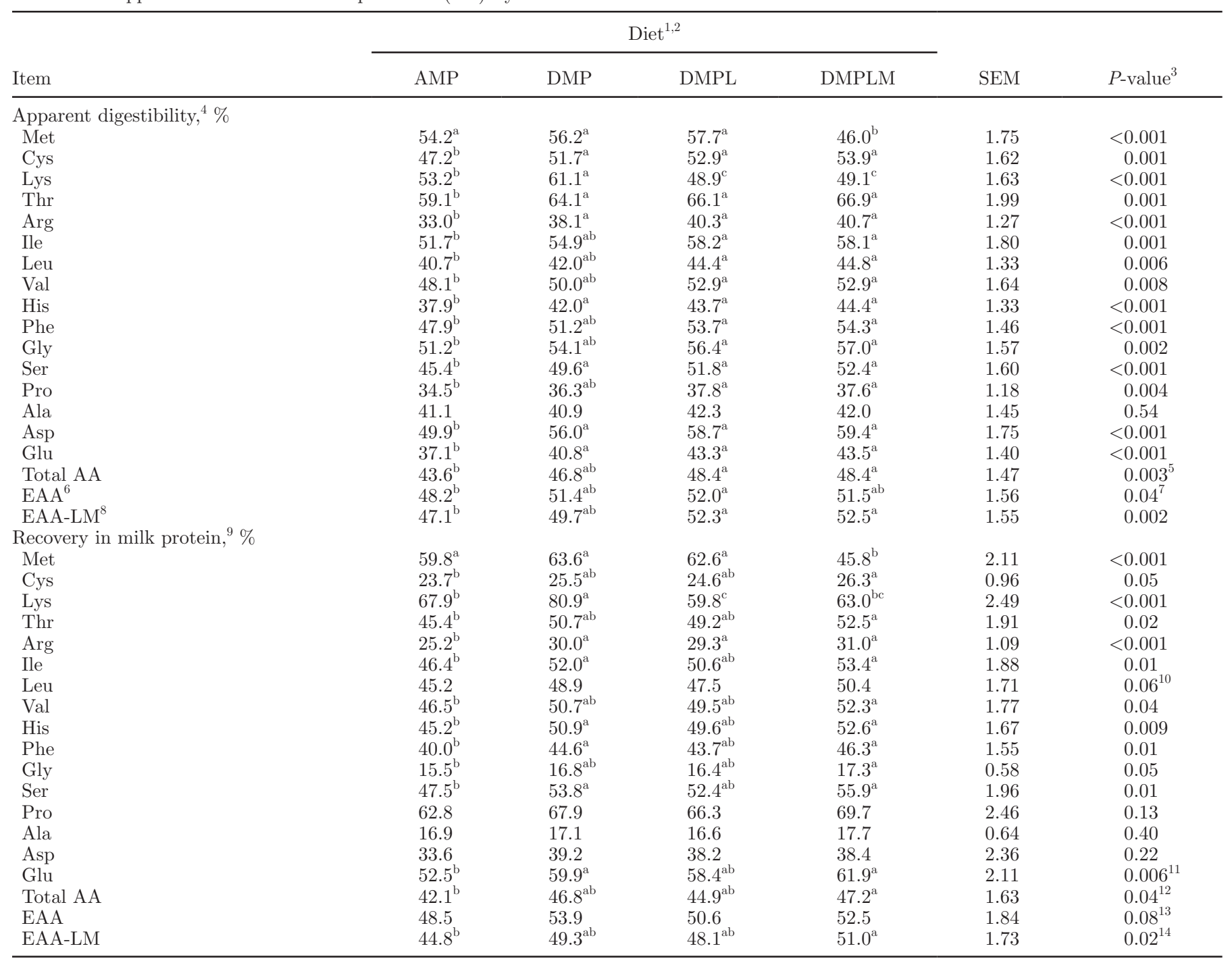

${ }^{\mathrm{a}-\mathrm{c}}$ Within a row, means without a common superscript letter differ $(P \leq 0.05)$.

${ }^{1} \mathrm{AMP}=$ diet adequate in MP; DMP $=$ diet deficient in MP; DMPL = diet deficient in MP supplemented with RPLys (AminoShure-L, Balchem Corporation, New Hampton, NY); DMPLM = diet deficient in MP supplemented with AminoShure-L and RPMet (Mepron, Evonik Industries AG, Hanau, Germany).

${ }^{2}$ Least squares means; $\mathrm{n}=29$ (represents number of observations used in the statistical analysis). Largest SEM published.

${ }^{3} P$-values for the main effect of treatment.

${ }^{4}[(\mathrm{AA}$ intake, $\mathrm{g} / \mathrm{d}-\mathrm{AA}$ in feces, $\mathrm{g} / \mathrm{d}) \div \mathrm{AA}$ intake, $\mathrm{g} / \mathrm{d}] \times 100$.

${ }^{5} \mathrm{AMP}$ versus DMP, $P=0.08$.

${ }^{6}$ Essential AA without Trp.

${ }^{7} \mathrm{AMP}$ versus DMPLM, $P=0.08$.

${ }^{8} \mathrm{EAA}-($ Lys + Met $)$

${ }^{9}($ AA secretion in milk protein, $\mathrm{g} / \mathrm{d} \div$ AA intake, $\mathrm{g} / \mathrm{d}) \times 100$.

${ }^{10} \mathrm{AMP}$ versus DMPLM, $P=0.04$.

${ }^{11} \mathrm{AMP}$ versus DMPL, $P=0.09$.

${ }^{12} \mathrm{AMP}$ versus DMP, $P=0.08$.

${ }^{13} \mathrm{AMP}$ versus DMP, $P=0.07$.

${ }^{14} \mathrm{AMP}$ versus DMP, $P=0.11$. 
Table 10. Effect of MP supply and rumen-protected AA supplementation on the apparent efficiency of utilization (\%) of NRC (2001)-predicted digestible EAA for milk protein synthesis ${ }^{1}$ in dairy cows

\begin{tabular}{lcccccc}
\hline & \multicolumn{7}{c}{ Diet $^{2,3}$} & & \\
\cline { 2 - 4 } Item & AMP & DMP & DMPL & DMPLM & SEM & $P$-value \\
\hline Met & $92.9^{\mathrm{b}}$ & $107.1^{\mathrm{a}}$ & $105.7^{\mathrm{a}}$ & $71.2^{\mathrm{c}}$ & 3.31 & $<0.001$ \\
Lys & $72.9^{\mathrm{b}}$ & $86.9^{\mathrm{a}}$ & $68.4^{\mathrm{b}}$ & $72.5^{\mathrm{b}}$ & 2.54 & $<0.001$ \\
Thr & $71.9^{\mathrm{b}}$ & $89.3^{\mathrm{a}}$ & $88.3^{\mathrm{a}}$ & $95.1^{\mathrm{a}}$ & 3.27 & $<0.001$ \\
Arg & $42.7^{\mathrm{b}}$ & $53.0^{\mathrm{a}}$ & $51.4^{\mathrm{a}}$ & $54.7^{\mathrm{a}}$ & 1.80 & $<0.001$ \\
Ile & $61.1^{\mathrm{b}}$ & $71.8^{\mathrm{a}}$ & $70.5^{\mathrm{a}}$ & $74.6^{\mathrm{a}}$ & 2.41 & $<0.001$ \\
Leu & $66.0^{\mathrm{b}}$ & $74.8^{\mathrm{a}}$ & $73.7^{\mathrm{ab}}$ & $78.6^{\mathrm{a}}$ & 2.50 & $0.003^{5}$ \\
Val & $74.1^{\mathrm{b}}$ & $88.4^{\mathrm{a}}$ & $86.1^{\mathrm{a}}$ & $91.1^{\mathrm{a}}$ & 2.81 & $<0.001$ \\
His & $77.6^{\mathrm{b}}$ & $93.4^{\mathrm{a}}$ & $91.7^{\mathrm{a}}$ & $98.8^{\mathrm{a}}$ & 3.02 & $<0.001$ \\
Phe & $73.0^{\mathrm{b}}$ & $91.9^{\mathrm{a}}$ & $89.4^{\mathrm{a}}$ & $94.2^{\mathrm{a}}$ & 2.94 & $<0.001$ \\
Total EAA & $67.7^{\mathrm{b}}$ & $80.6^{\mathrm{a}}$ & $76.0^{\mathrm{ab}}$ & $79.1^{\mathrm{a}}$ & 2.57 & $0.003^{7}$ \\
\hline
\end{tabular}

${ }^{\mathrm{a}-\mathrm{c}}$ Within a row, means without a common superscript letter differ $(P \leq 0.05)$.

${ }^{1}$ Calculated as: $\{$ EAA secreted in milk protein $\div$ [predicted flow of digestible EAA - estimated EAA requirements for maintenance] $\} \times 100$, all units are grams per day; estimations from NRC (2001) with AA composition from Cornell Net Carbohydrate and Protein System (O'Connor et al., 1993).

${ }^{2} \mathrm{AMP}=$ diet adequate in MP; DMP $=$ diet deficient in MP; DMPL $=$ diet deficient in MP supplemented with RPLys (AminoShure-L, Balchem Corporation, New Hampton, NY); DMPLM = diet deficient in MP supplemented with AminoShure-L and RPMet (Mepron, Evonik Industries AG, Hanau, Germany).

${ }^{3}$ Least squares means; $\mathrm{n}=29$ (represents number of observations used in the statistical analysis). Largest SEM published.

${ }^{4} P$-values for the main effect of treatment.

${ }^{5} \mathrm{AMP}$ versus DMPL, $P=0.07$.

${ }^{6}$ Essential AA without Trp.

${ }^{7} \mathrm{AMP}$ versus DMPL, $P=0.07$.

intake can be indicative of the extent of urea- $\mathrm{N}$ recycled and used for microbial protein synthesis in the rumen. Data by Kaufman (1980) for dairy cows fitted with reentrant cannulas showed that this ratio increased from 70 to $150 \%$ as dietary protein concentration decreased from 17 to $7 \%$. Diets with CP concentrations of around $16 \%$ resulted in a positive rumen $\mathrm{N}$ balance, which means net $\mathrm{N}$ loss from the rumen of approximately $1.1 \mathrm{~g}$ of $\mathrm{N} / \mathrm{kg}$ of DMI (Broderick et al., 2010). In that meta-analysis of changeover design studies that used the omasal technique to measure $\mathrm{N}$ outflow from the rumen, milk production was on average approximately $29 \mathrm{~kg} / \mathrm{d}$. When protein-deficient diets $(13.5 \% \mathrm{CP})$ were fed to cows milking 36 to $38 \mathrm{~kg} / \mathrm{d}$ in a Latin square design trial, omasal flow of NAN was about $120 \%$ of the total $\mathrm{N}$ intake, indicating substantial recycling of $\mathrm{N}$ to the rumen (Olmos Colmenero and Broderick, 2006b). To what extent urea recycling can sustain rumen function in the long term is unknown. A meta-analysis focused on carry-over effects as related to experimental design concluded that changeover designs are as accurate as continuous designs in estimating feed intake and milk production responses to dietary treatment, but also pointed out that treatments that result in mobilization of body fat and protein, such as in the study by Giallongo et al. (2014), may be an exception (Huhtanen and Hetta, 2012).
Apparent total-tract digestibility of all EAA was generally increased by the DMP diets, except for Met and Lys with the RPAA-supplemented diets. Similar trends were observed for the recoveries of dietary AA in milk protein. These results are not surprising because EAA intake was greater for the control diet and secretion of EAA in milk protein was similar among diets. Apparent digestibility of Lys was the highest of all EAA and Lys recovery in milk was the highest, $81 \%$ for the DMP diet. Based on NRC (2001), the DMP diet was about $-26 \mathrm{~g} / \mathrm{d}$ (or about $4 \%$ ) deficient in dLys, which may be the reason for the high Lys recovery in milk protein. Deficiency of dMet, however, was greater (around 26\%), but Met recovery in milk protein was lower than that of Lys and the increase for DMP, over the AMP diet, was smaller than for Lys (6 vs. 19\%). The uptake of Lys by the mammary gland exceeds its output in milk (Linzell et al., 1969; Lapierre et al., 2008), which suggests that the actual uptake of dLys by the mammary gland was greater than Lys secreted in milk protein. The recovery of Lys in milk protein for the RPLys-supplemented diet was about $26 \%$ lower and that of Met for the RPMet-supplemented diet was $28 \%$ lower than DMP and DMPL, respectively. Because secretion of Lys and Met in milk protein did not change as a result of RPAA supplementation, the recoveries of these AA in milk protein decreased. If Lys and Met 


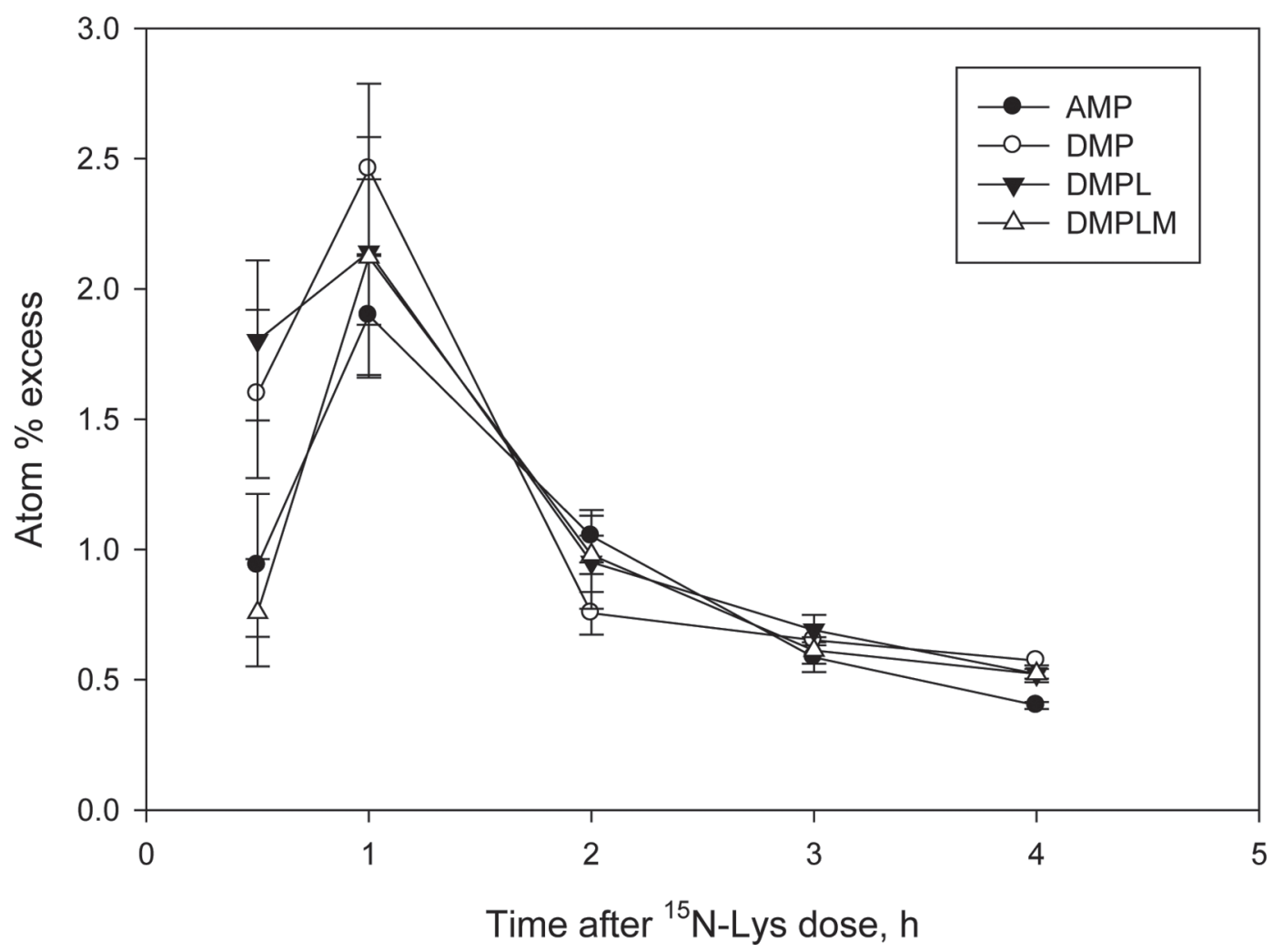

Figure $1 .{ }^{15} \mathrm{~N}$ enrichment of blood plasma Lys (means $\pm \mathrm{SE}$ ) in dairy cows pulse-dosed with ${ }^{15} \mathrm{~N}$-Lys in the abomasum. AMP $=$ diet adequate in MP; DMP = diet deficient in MP; DMPL = diet deficient in MP supplemented with rumen-protected (RP) Lys (AminoShure-L, Balchem Corporation, New Hampton, NY); DMPLM = diet deficient in MP supplemented with AminoShure-L and RPMet (Mepron, Evonik Industries AG, Hanau, Germany). Average values: 0.99, 1.21, 1.21, and 1.00 at \% excess, AMP, DMP, DMPL, and DMPLM, respectively. Data for time points 3 and $4 \mathrm{~h}$ are from period 4 only. Main effect of treatment, $P=0.64$; effect of time, $P<0.001$; treatment $\times$ time interaction, $P=0.49$ ( $\mathrm{SEM}=0.21 ; \mathrm{n}=99 ;$ number of observations used in the statistical analysis).

intakes were corrected for these AA supplied with the rumen-protected products, the recoveries of Lys and Met for the DMPL or DMPLM diets, or both, were similar to those for the DMP diet: $81 \pm 2.4$ and $66 \pm$ $2.5 \%$ for Lys and Met, respectively. Thus, based on these estimates, no net recovery of the supplemental RPLys and RPMet in milk protein was found in this study. Vyas and Erdman (2009) estimated marginal efficiencies of metabolizable Lys and Met use for MPY as low as $25 \%$ for Lys and $12 \%$ for Met as metabolizable AA supply increased by postruminal infusion or dietary supplementation of RPLys and RPMet. Unlike the current study, the Vyas and Erdman (2009) analysis found a response, although declining, in milk protein yield with increasing RPLys and RPMet supplementation.

As several analyses have pointed out, the efficiency of utilization of MP or MP-AA for milk protein synthesis depends on a supply-demand of MP-AA formula (Whitelaw et al., 1986; Doepel et al., 2004; Vyas and Erdman, 2009). The efficiencies estimated in the current study also confirm this concept; with all EAA, the efficiency of use of MP-AA for milk protein synthesis increased for the DMP diet, compared with AMP: from 13\% (Leu) to 24 to 26\% (Thr, Arg, and Phe). The efficiencies of utilization of Met and Lys, considered first and second limiting AA in lactating dairy cows, increased by 15 and $19 \%$, respectively, with the DMP diet and that of His (which may also be a limiting AA in the dietary conditions of the current trial; Lee et al., 2012c), by $20 \%$. As expected, supplementation of DMP with RPLys and RPMet resulted in decreased efficiencies of Lys and Met utilization, compared with DMP. The estimated efficiency of conversion of MP-Met into milk protein was the highest, which is in agreement with the generally higher efficiency of utilization of dietary Met by the dairy cow and established high efficiency of extraction of group 1 AA, including Met (Mepham, 1982). These estimates, however, have to be interpreted with caution due to the likely overestimation of maintenance requirements by NRC (2001). Ouellet et al. (2010) showed, for example, that MFP requirements (calculated as endogenous fecal $\mathrm{N}$ losses) for the conditions of their experiment were $40 \%$ or lower of the NRC (2001) estimates. As pointed out by Arriola Apelo et al. (2014), 


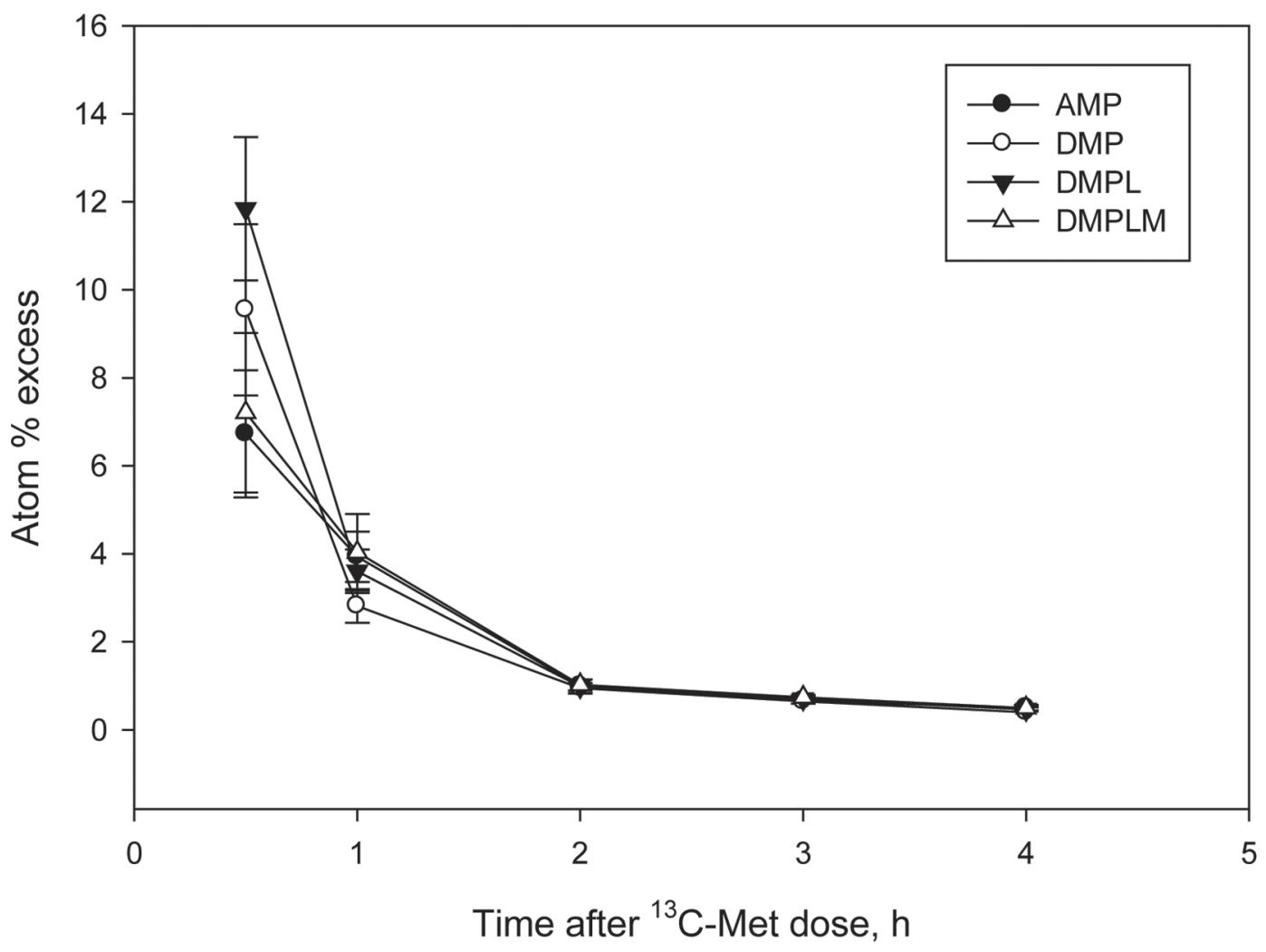

Figure 2. ${ }^{13} \mathrm{C}$ enrichment of blood plasma Met (means \pm SE) in dairy cows pulse-dosed with ${ }^{13} \mathrm{C}-$ Met in the abomasum. AMP $=$ diet adequate in MP; DMP = diet deficient in MP; DMPL = diet deficient in MP supplemented with rumen-protected (RP) Lys (AminoShure-L, Balchem Corporation, New Hampton, NY); DMPLM = diet deficient in MP supplemented with AminoShure-L and RPMet (Mepron, Evonik Industries AG, Hanau, Germany). Average values: 2.60, 2.88, 3.49, and 2.68 at \% excess, AMP, DMP, DMPL, and DMPLM, respectively. Data for time points 3 and $4 \mathrm{~h}$ are from period 4 only. Main effect of treatment, $P=0.79$; effect of time, $P<0.001$; treatment $\times$ time interaction, $P$ $=0.49(\mathrm{SEM}=0.90 ; \mathrm{n}=100 ;$ number of observations used in the statistical analysis $)$.

any error in estimating maintenance requirements (for MP or individual AA) will influence the estimates for efficiency of MP use for milk protein synthesis. Another possible reason for the high efficiency coefficients of AA use in our study could be, as suggested by Lapierre et al. (2006), underprediction of flow of certain key AA (including Met) by NRC (2001).

The objective of infusing postruminally stable isotope-labeled Lys and Met was to estimate rates of disappearance of Lys and Met from blood plasma as affected by dietary treatment. For most EAA secreted in milk protein, plasma is the primary source of precursor AA (Mepham, 1982) and we were expecting that the isotope data would provide an insight into the rate of utilization of plasma Lys and Met for milk protein synthesis. The IE decay curves observed were similar to those reported by others for ${ }^{15} \mathrm{~N}$-Lys or ${ }^{13} \mathrm{C}$-Met (Borucki Castro et al., 2008, and Lapierre et al., 2012, respectively). The estimated rates of decline in ${ }^{15} \mathrm{~N}$ - or ${ }^{13} \mathrm{C}-\mathrm{IE}$, using a simple one-pool exponential model, suggested that the labeled AA tended to be extracted from plasma at a faster rate for the DMP diet, compared with AMP or DMPL (Lys) and DMPLM (Lys and Met). Although not analyzed statistically, the data may suggest a more rapid mobilization of plasma Lys and Met in cows fed MP-deficient diets and are in agreement with the significantly greater efficiency of utilization of MP-AA for milk protein synthesis with the MP-deficient diets. Bequette et al. (2000) reported a sharp increase in the efficiency of the mammary gland to extract His (and other EAA) when a His deficient diet was fed to lactating goats. In the current study, a clear difference was observed in the IE pattern between Lys and Met. The peak IE of plasma ${ }^{15} \mathrm{~N}-\mathrm{Lys}$ was not reached until $1 \mathrm{~h}$ postdose, whereas peak IE for ${ }^{13} \mathrm{C}$-Met was at or before $30 \mathrm{~min}$ postdose. One possible explanation for the delayed appearance of ${ }^{15} \mathrm{~N}$-Lys (compared with ${ }^{13} \mathrm{C}$-Met) in plasma is slower absorption rate of Lys versus Met in the small intestine. Wilson and Webb (1990), for example, reported a considerably greater rate of transport of Met than Lys in both ileal and jejunal tissue of cattle. 


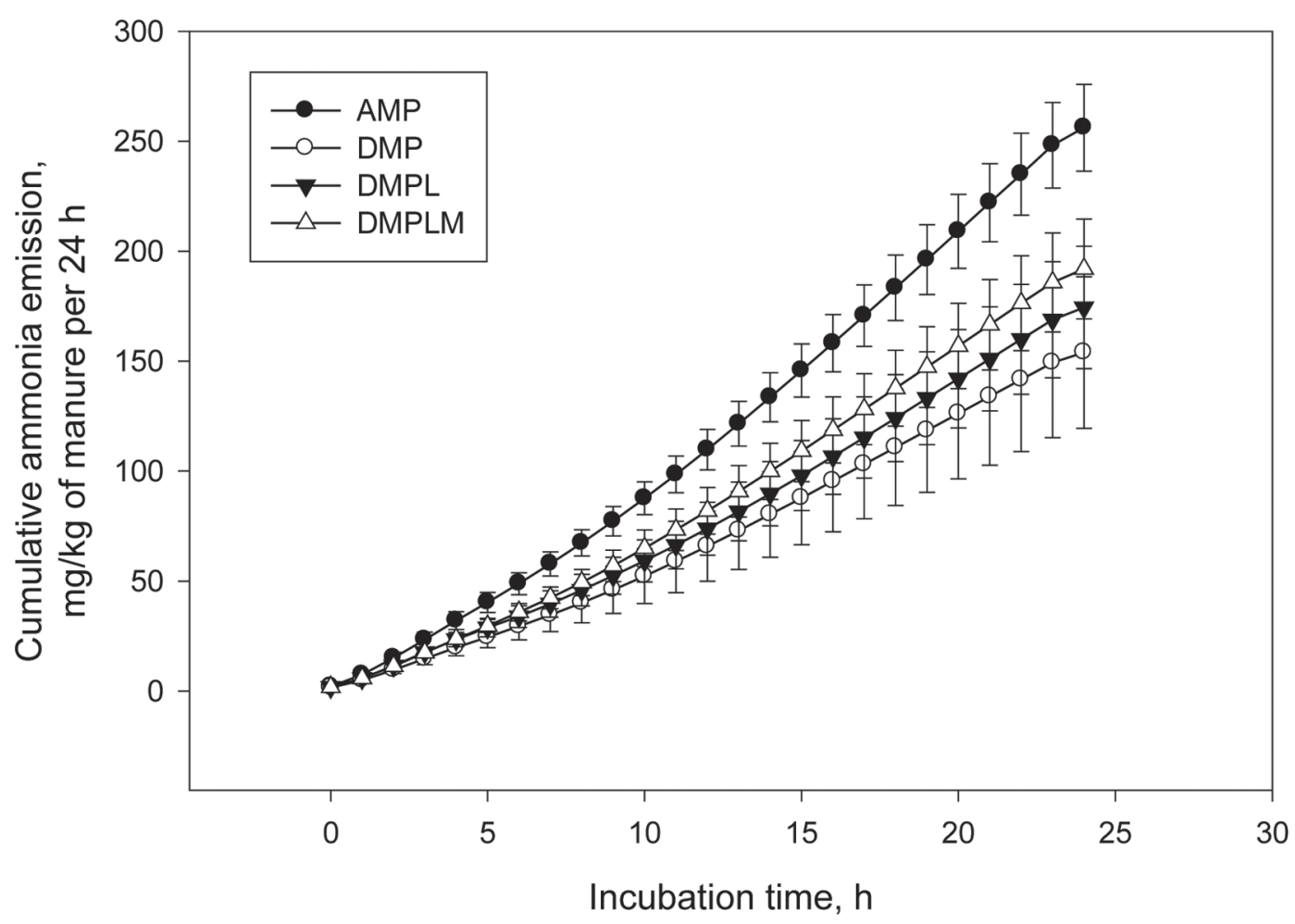

Figure 3. Cumulative ammonia emission (means $\pm \mathrm{SE}$ ) from reconstituted manure from dairy cows fed diets adequate or deficient in MP with or without supplementation with rumen-protected Lys and Met. AMP = diet adequate in MP; DMP = diet deficient in MP; DMPL = diet deficient in MP supplemented with rumen-protected (RP) Lys (AminoShure-L, Balchem Corporation, New Hampton, NY); DMPLM = diet deficient in MP supplemented with AminoShure-L and RPMet (Mepron, Evonik Industries AG, Hanau, Germany). Average cumulative values: $249^{\mathrm{a}}, 155^{\mathrm{b}}, 167^{\mathrm{b}}$, and $192^{\mathrm{ab}} \mathrm{mg} / \mathrm{kg}$ of manure per $24 \mathrm{~h}$ (AMP, DMP, DMPL, and DMPLM, respectively; means without a common superscript letter differ at $P<0.05 ;$ AMP vs. DMPLM, $P=0.07$ ). Main effect of treatment, $P=0.003$ (SEM $=20.9 ; \mathrm{n}=29 ;$ number of observations used in the statistical analysis).

\section{CONCLUSIONS}

In this Latin square experiment, diets deficient in MP by 256 to $305 \mathrm{~g} / \mathrm{d}$ and supplementation with rumen-protected Lys and Met did not affect feed intake, milk production and composition, and digestibility of the fiber fractions, but decreased urinary $\mathrm{N}$ excretion, compared with a diet that was close to meeting the MP requirements of dairy cows milking around 40 to $42 \mathrm{~kg} / \mathrm{d}$. The MP-deficient diets also decreased ammonia concentration in ruminal fluid and the ammoniaemitting potential of manure. Supplementation with rumen-protected Met increased or tended to increase plasma Met concentration, but the rumen-protected Lys product had no effect on plasma Lys. Apparent digestibility and the recovery of dietary EAA in milk protein were generally increased with the MP-deficient diets, except for Lys and Met for the diets supplemented with rumen-protected Lys and Met. The latter were apparently not used for milk protein synthesis in the conditions of this experiment. Estimated efficiency of utilization of digestible EAA for milk protein synthesis was greater for the MP-deficient diets. This finding is in line with previous reports based on experimental work or modeling efforts and emphasizes the importance of incorporating variable efficiency of utilization of AA in protein nutrition models for dairy cows. Stable isotopelabeled Lys and Met were extracted from blood plasma at a faster rate for the MP-deficient diets, compared with the MP-adequate diet. Overall, this study confirmed conclusions from previous analyses that the efficiency of utilization of dietary EAA will increase with decreasing MP-AA supply.

\section{ACKNOWLEDGMENTS}

This study was partially supported by funds from Evonik Industries AG (Hanau, Germany). The authors thank Balchem Corp. (New Hampton, NY) for providing the AminoShure-L for the trial and the staff of the Department of Animal Science Dairy Center at Pennsylvania State University for their conscientious care of the experimental cows. 


\section{REFERENCES}

AOAC International. 1995. Official Methods of Analysis. 15th ed. AOAC Int., Arlington, VA.

AOAC International. 2000. Official Methods of Analysis. 17th ed. AOAC Int., Arlington, VA.

Arriola Apelo, S. I., J. R. Knapp, and M. D. Hanigan. 2014. Invited review: Current representation and future trends of predicting amino acid utilization in the lactating dairy cow. J. Dairy Sci. 97:4000-4017.

Atasoglu, C., C. J. Newbold, and R. J. Wallace. 2001. Incorporation of $[15 \mathrm{~N}]$ ammonia by the cellulolytic ruminal bacteria Fibrobacter succinogenes BL2, Ruminococcus albus SY3, and Ruminococcus flavefaciens 17. Appl. Environ. Microbiol. 67:2819-2822.

Bequette, B. J., M. D. Hanigan, A. G. Calder, C. K. Reynolds, G. E. Lobley, and J. C. MacRae. 2000. Amino acid exchange by the mammary gland of lactating goats when histidine limits milk production. J. Dairy Sci. 83:765-775.

Block, R. J., and D. Bolling. 1951. The Amino Acid Composition of Proteins and Foods. 2nd ed. Thomas, Springfield, IL.

Borucki Castro, S. I., H. Lapierre, L. E. Phillip, P. W. Jardon, and R. Berthiaume. 2008. Towards non-invasive methods to determine the effect of treatment of soybean meal on lysine availability in dairy cows. Animal 2:224-234.

Broderick, G. A. 2003. Effects of varying dietary protein and energy levels on the production of lactating dairy cows. J. Dairy Sci. 86:1370-1381.

Broderick, G. A., P. Huhtanen, S. Ahvenjärvi, S. M. Reynal, and K. J. Shingfield. 2010. Quantifying ruminal nitrogen metabolism using the omasal sampling technique in cattle-A meta-analysis. J. Dairy Sci. 93:3216-3230.

Broderick, G. A., L. D. Satter, and A. E. Harper. 1974. Use of plasma amino acid concentration to identify limiting amino acids for milk production. J. Dairy Sci. 57:1015-1023.

Calder, A. G., and A. Smith. 1988. Stable isotope ratio analysis of leucine and ketoisocaproic acid in blood plasma by gas chromatography/mass spectrometry. Use of tertiary butyldimethylsilyl derivatives. Rapid Commun. Mass Spectrom. 2:14-16.

Chaney, A. L., and E. P. Marbach. 1962. Modified reagents for determination of urea and ammonia. Clin. Chem. 8:130-132.

Chen, X. B. 1989. Excretion of purine derivatives by sheep and cattle and its use for estimation of absorbed microbial protein. $\mathrm{PhD}$ Thesis. University of Aberdeen, United Kingdom.

de Lange, C. F. M., W. C. Sauer, and W. B. Souffrant. 1989. The effect of protein status of the pig on the recovery and amino acid composition of endogenous protein in digesta collected from the distal ileum. J. Anim. Sci. 67:755-762.

Doepel, L., D. Pacheco, J. J. Kennelly, M. D. Hanigan, I. F. Lopez, and H. Lapierre. 2004. Milk protein synthesis as a function of amino acid supply. J. Dairy Sci. 87:1279-1297.

European Commission. 2009. 2009/150/EC Commission regulation laying down the methods of sampling and analysis for the official control of feed. Off. J. Eur. Union L 54:1-130.

Frank, B., M. Persson, and G. Gustafsson. 2002. Feeding dairy cows for decreased ammonia emission. Livest. Prod. Sci. 76:171-179.

Giallongo, F., J. Oh, T. Frederick, H. Weeks, A. N. Hristov, H. Lapierre, R. A. Patton, A. Gehman, and C. Parys. 2014. Effects of slow-release urea, rumen-protected methionine, and histidine on performance of dairy cows fed metabolizable protein-deficient diets. J. Dairy Sci. 97(Suppl. 1). In press.

Griel, L. C. Jr., R. A. Patton, R. D. McCarthy, and P. T. Chandler. 1968. Milk production response to feeding methionine hydroxy analog to lactating dairy cows. J. Dairy Sci. 51:1866-1868.

Hristov, A. N., T. A. McAllister, and K.-J. Cheng. 1998. Effect of dietary or abomasal supplementation of exogenous polysaccharidedegrading enzymes on rumen fermentation and nutrient digestibility. J. Anim. Sci. 76:3146-3156.

Hristov, A. N., and J. K. Ropp. 2003. Effect of dietary carbohydrate composition and availability on utilization of ruminal ammonia nitrogen for milk protein synthesis in dairy cows. J. Dairy Sci. $86: 2416-2427$.
Hristov, A. N., G. Varga, T. Cassidy, M. Long, K. Heyler, K. R. Karnati, B. Corl, C. J. Hovde, and I. Yoon. 2010. Effect of yeast culture on ruminal fermentation and nutrient utilization in dairy cows. J. Dairy Sci. 93:682-692.

Huhtanen, P., and M. Hetta. 2012. Comparison of feed intake and milk production responses in continuous and change-over design dairy cow experiments. Livest. Sci. 143:184-194.

Huhtanen, P., and A. N. Hristov. 2009. A meta-analysis of the effects of protein concentration and degradability on milk protein yield and milk N efficiency in dairy cows. J. Dairy Sci. 92:3222-3232.

Ipharraguerre, I. R., and J. H. Clark. 2005. Impacts of the source and amount of crude protein on the intestinal supply of nitrogen fractions and performance of dairy cows. J. Dairy Sci. 88:(E. Suppl.):E22-E37.

Kaufman, W. 1980. Protein degradation and synthesis within the reticulo-rumen in relation to milk protein synthesis. Int. Dairy Fed. Bull. 125:152-158.

Kebreab, E., J. France, J. A. N. Mills, R. Allison, and J. Dijkstra 2002. A dynamic model of $\mathrm{N}$ metabolism in the lactating dairy cow and an assessment of impact of $\mathrm{N}$ excretion on the environment. J. Anim. Sci. 80:248-259.

Kröber, T. F., D. R. Kulling, H. Menzi, F. Sutter, and M. Kreuzer. 2000. Quantitative effects of feed protein reduction and methionine on nitrogen use by cows and nitrogen emission from slurry. J. Dairy Sci. 83:2941-2951.

Lapierre, H., G. Holtrop, A. G. Calder, J. Renaud, and G. E. Lobley. 2012. Is D-methionine bioavailable to the dairy cow? J. Dairy Sci. 95:353-362.

Lapierre, H., D. R. Ouellet, L. Doepel, G. Holtrop, and G. E. Lobley. 2008. Histidine, lysine and methionine: From metabolism to balanced dairy rations. Pages 19-36 in Proc. 44th Eastern Nutrition Conference of the Animal Nutrition Association of Canada (ANAC), University of Guelph, Guelph, ON, Canada. University of Guelph, Guelph, ON, Canada.

Lapierre, H., D. Pacheco, R. Berthiaume, D. R. Ouellet, C. G. Schwab, P. Dubreuil, G. Holtrop, and G. E. Lobley. 2006. What is the true supply of amino acids for a dairy cow? J. Dairy Sci. 89(E. Suppl.):E1-E14.

Lee, C., A. N. Hristov, T. W. Cassidy, K. S. Heyler, H. Lapierre, G. A. Varga, M. J. de Veth, R. A. Patton, and C. Parys. 2012c. Rumenprotected lysine, methionine, and histidine increase milk protein yield in dairy cows fed metabolizable protein-deficient diet. J. Dairy Sci. 95:6042-6056.

Lee, C., A. N. Hristov, C. J. Dell, G. W. Feyereisen, J. Kaye, and D. Beegle. 2012a. Effect of dietary protein concentration on ammonia and greenhouse gas emissions from dairy manure. J. Dairy Sci. 95:1930-1941.

Lee, C., A. N. Hristov, K. S. Heyler, T. W. Cassidy, H. Lapierre, G. A. Varga, and C. Parys. 2012b. Effects of metabolizable protein supply and amino acids supplementation on nitrogen utilization, production and ammonia emissions from manure in dairy cows. J. Dairy Sci. 95:5253-5268.

Lee, C., A. N. Hristov, K. S. Heyler, T. W. Cassidy, M. Long, B. A. Corl, and S. K. R. Karnati. 2011. Effects of dietary protein concentration and coconut oil supplementation on nitrogen utilization and production in dairy cows. J. Dairy Sci. 94:5544-5557.

Lemosquet, S., J. Guinard-Flament, G. Raggio, C. Hurtaud, J. van Milgen, H. Lapierre, and G. M. Crovetto. 2010. How does increasing protein supply or glucogenic nutrients modify mammary metabolism in lactating dairy cows? Pages 175-186 in Energy and Protein Metabolism and Nutrition. 3rd EAAP International Symposium on Energy and Protein Metabolism and Nutrition, Parma, Italy, September 6-10, 2010. Wageningen Academic Publishers, Wageningen, the Netherlands.

Linzell, J. L., T. B. Mepham, E. F. Annison, and C. E. West. 1969 Mammary metabolism in lactating sows: Arteriovenous differences of milk precursors and the mammary metabolism of $\left[{ }^{14} \mathrm{C}\right]$ glucose and $\left[{ }^{14} \mathrm{C}\right]$ acetate. Br. J. Nutr. 23:319-332.

Martineau, R., C. Côrtes, I. Ortigues-Marty, D. R. Ouellet, and H. Lapierre. 2014. Evaluation of equations predicting the net portal 
appearance of amino acid nitrogen in ruminants. J. Dairy Sci. 97:1670-1681.

Mepham, T. B. 1982. Amino acid utilization by lactating mammary gland. J. Dairy Sci. 65:287-298.

Metcalf, J. A., R. J. Mansbridge, J. S. Blake, J. D. Oldham, and J. R. Newbold. 2008. The efficiency of conversion of metabolisable protein into milk true protein over a range of metabolizable protein intakes. Animal 2:1193-1202.

NRC. 2001. Nutrient Requirements of Dairy Cattle. 7th rev. ed. Natl. Acad. Sci., Washington, DC.

O'Connor, J. D., C. J. Sniffen, D. G. Fox, and W. Chalupa. 1993. A net carbohydrate and protein system for evaluating cattle diets: IV. Predicting amino acid adequacy. J. Anim. Sci. 71:1298-1311.

Olmos Colmenero, J. J., and G. A. Broderick. 2006a. Effect of dietary crude protein concentration on milk production and nitrogen utilization in lactating dairy cows. J. Dairy Sci. 89:1704-1712.

Olmos Colmenero, J. J., and G. A. Broderick. 2006b. Effect of dietary crude protein concentration on ruminal nitrogen metabolism in lactating dairy cows. J. Dairy Sci. 89:1694-1703.

Ouellet, D. R., R. Berthiaume, G. Holtrop, G. E. Lobley, R. Martineau, and H. Lapierre. 2010. Effect of method of conservation of timothy on endogenous nitrogen flows in lactating dairy cows. J. Dairy Sci. 93:4252-4261.

Patton, R. A. 2010. Effect of rumen-protected methionine on feed intake, milk production, true milk protein concentration, and true milk protein yield, and the factors that influence these effects: A meta-analysis. J. Dairy Sci. 93:2105-2118.

Paul, J. W., N. E. Dinn, T. Kannangara, and L. J. Fisher. 1998. Protein content in dairy cattle diets affects ammonia losses and fertilizer nitrogen value. J. Environ. Qual. 27:528-534.

Raggio, G., D. Pacheco, R. Berthiaume, G. E. Lobley, D. Pellerin, G. Allard, P. Dubreuil, and H. Lapierre. 2004. Effect of level of metabolizable protein on splanchnic flux of amino acids in lactating dairy cows. J. Dairy Sci. 87:3461-3472.

Reynolds, C. K., and N. B. Kristensen. 2008. Nitrogen recycling through the gut and the nitrogen economy of ruminants: An asynchronous symbiosis. J. Anim. Sci. 86(E. Suppl.):E293-E305.
Robinson, P. H. 2010. Impacts of manipulating ration metabolizable lysine and methionine levels on the performance of lactating dairy cows: A systematic review of the literature. Livest. Sci. 127:115126.

Schneider, B. H., and W. P. Flatt. 1975. The Evaluation of Feeds Through Digestibility Experiments. University of Georgia Press, Athens.

Schwab, C. G., P. Huhtanen, C. W. Hunt, and T. Hvelplund. 2005. Nitrogen Requirements of cattle. Pages 13-70 in Nitrogen and Phosphorus Nutrition of Cattle and Environment. E. Pfeffer and A. N. Hristov, ed. CAB International, Wallingford, UK.

Van Soest, P. J., J. B. Robertson, and B. A. Lewis. 1991. Methods for dietary fiber, neutral detergent fiber, and nonstarch polysaccharides in relation to animal nutrition. J. Dairy Sci. 74:3583-3597.

Vanhatalo, A., P. Huhtanen, V. Toivonen, and T. Varvikko. 1999. Response of dairy cows fed grass silage diets to abomasal infusions of histidine alone or in combinations with methionine and lysine. J. Dairy Sci. 82:2674-2685.

Virtanen, A. I. 1966. Milk production of cows on protein-free feed. Science 153:1603-1614.

Vyas, D., and R. A. Erdman. 2009. Meta-analysis of milk protein yield responses to lysine and methionine supplementation. J. Dairy Sci. 92:5011-5018.

Wheeler, E. F., P. A. Topper, N. E. Brown, and G. A. Varga. 2007. Multiple-chamber steady-state gas emission detection from dairy manure slurry. Proc. Int. Symp. Air Quality and Waste Management for Agriculture, Broomfield, CO. ASABE Publication Number 701P0907cd. Am. Soc. Agric. Biol. Eng., St. Joseph, MI.

Whitelaw, F. G.. J. S. Milne, E. R. Orskov, and J. S. Smith. 1986. The nitrogen and energy metabolism of lactating cows given abomasal infusions of casein. Br. J. Nutr. 55:537-556.

Wilson, J. W., and K. E. Webb Jr.. 1990. Lysine and methionine transport by bovine jejunal and ileal brush border membrane vesicles. J. Anim. Sci. 68:504-514.

Yang, C. M. Jr., and G. A. Varga. 1989. Effect of three concentrate feeding frequencies on rumen protozoa, rumen digesta kinetics, and milk yield in dairy cows. J. Dairy Sci. 72:950-957. 